\title{
Federal Interference with State Prosecutions: The Cases Dombrowski Forgot
}

\author{
Douglas Laycock $\dagger$
}

Dombrowski $v$. Pfister ${ }^{1}$ held that in certain circumstances federal courts could enjoin threatened prosecutions under allegedly unconstitutional state statutes. This decision has generally been viewed as a significant but short-lived expansion of federal power. The conventional wisdom is that such injunctions were made available by Ex parte Young, ${ }^{2}$ substantially foreclosed by subsequent developments culminating in Douglas $v$. City of Jeanette, ${ }^{3}$ granted anew by Dombrowski, and greatly restricted once again in Younger v. Harris. ${ }^{4}$

The thesis of this article is that Dombrowski actually limited federal power. Careful review of the pre-Dombrowski precedents indicates that injunctions against threatened prosecutions issued routinely and rested on a sound doctrinal basis. What is significant about Dombrowski is not that an injunction issued, but that the injunction was treated as exceptional instead of routine and that new limitations on the availability of injunctions were introduced.

If this thesis is accepted, Dombrowski presents important historical and jurisprudential problems. There is little evidence to suggest that Dombrowski's break with precedent was deliberate, and even if it were, this would not explain why the decision was widely received as a great victory for civil libertarians and the social activists of the sixties. In fact, Dombrowski appears to have been a mistake; incredibly, the Court and most of the profession seem to have overlooked the two preceding decades of Supreme Court practice. Such a mistake raises questions about the reliability of a legal system that depends on judicial opinions to formulate and transmit doctrine, and about the proper judicial response to its discovery.

These broad questions have specific implications for the law currently governing federal prospective relief from unconstitutional

$\dagger$ Assistant Professor of Law, The University of Chicago. Paul Bator, David Currie, Owen Fiss, William Hodes, John Langbein, Martin Redish, Geoffrey Stone, and Ralph Whitten offered helpful comments on earlier drafts. Paul Beach and Joseph Markowitz provided invaluable research assistance.

t 380 U.S. 479 (1965).

209 U.S. 123 (1908).

319 U.S. 157 (1943).

401 U.S. 37 (1971). 
state statutes-injunctions against enforcement or declaratory judgments of unconstitutionality. ${ }^{5}$ I have argued elsewhere ${ }^{6}$ that the Younger doctrine denies prospective relief in situations in which supposedly adequate criminal remedies are not adequate at all. The most important of these involve citizens engaged in a continuing course of conduct who are prosecuted for past violations of an allegedly invalid state law and are unable to get prompt relief or authoritative resolution of their constitutional claims with respect to future violations. Since, as I will argue here, such undue extensions of Younger resulted at least in part from a mistaken view of the precedents, a view originating in Dombrowski, the Court has a special obligation to adjust the Younger doctrine in light of the arguments and authority previously overlooked.

The first three parts of this article review Dombrowski, the preDombrowski precedents, and the doctrinal effects of Dombrowski's break with those precedents. Part IV explores the very sketchy evidence available on the question why Dombrowski was decided as it was. Finally, Part V briefly poses the larger jurisprudential questions raised by judicial mistakes and then considers the implications for the Younger doctrine of a corrected understanding of preDombrowski law.

\section{The Conventional View of Dombrowski}

Dombrowski arose out of a dispute between a civil rights organization and various Louisiana officials. The individual plaintiffs had been arrested and charged with violating two communist-control laws. ${ }^{7} \mathrm{~A}$ state court had subsequently quashed the arrest warrants, but state officials continued to threaten prosecution. The plaintiffs then filed the federal lawsuit, seeking an injunction against further proceedings under the two laws. Judge Wisdom, sitting as one member of a three-judge district court, issued a temporary restraining order. The three-judge court then assembled and, over Judge Wisdom's dissent, vacated the restraining order and dismissed the complaint. ${ }^{8}$ The opinion, citing Douglas $v$. City of Jeanette, ${ }^{9}$ held that federal courts should not enjoin state prosecutions in the absence of extraordinary circumstances not found to be present. Following this

3 See Laycock, Federal Interference with State Prosecutions: The Need for Prospective Relief, 1977 Sur. CT. REv. 193, 200.

- Id. at 199-222.

7380 U.S. at 482 n.1.

- Dombrowski v. Pfister, 227 F. Supp. 556 (E.D. La. 1964), rev'd, 380 U.S. 479 (1965).

- 319 U.S. 157 (1943). 
decision, the plaintiffs were indicted under on $e^{10}$ of the two statutes.

The Supreme Court reversed, holding the statute under which the plaintiffs had been indicted to be an overbroad regulation of speech $^{\text {II }}$ and disposing of four arguments against reaching the merits: Pullman abstention, ${ }^{12}$ the ripeness requirement, the AntiInjunction Act, ${ }^{13}$ and the irreparable injury requirement. Three of these arguments need not detain us. The Court's treatment of Pullman abstention, ${ }^{14}$ a postponement of federal jurisdiction if a state court might by statutory construction obviate the need to reach a difficult constitutional question, had little immediate impact on the issues involved. The ripeness requirement, which precludes prospective relief unless there is a reasonable prospect that the challenged law will be enforced, was held met with respect to only one of the statutes, a remarkably stringent application of the requirement. ${ }^{15}$ The Anti-Injunction Act, which prohibits a federal court from issuing an injunction to stay proceedings that are already pending in a state court, ${ }^{16}$ was construed narrowly and held inapplicable. ${ }^{17}$ The Court found that the indictments had not been pending at the time the federal complaint was filed and would not have been pending at all if Judge Wisdom's restraining order had not been erroneously vacated..$^{18}$ Apparently the state-court proceedings on the warrants and motions to quash did not count. These three holdings are of only limited importance to the present analysis, but their implications will be discussed where relevant in Parts III and IV.

The heart of Dombrowski, and the concern of this article, is its treatment of the irreparable injury requirement. ${ }^{19}$ The defendants

10380 U.S. at 488.

"Id. at 492-96.

12 See Railroad Comm'n v. Pullman Co., 312 U.S. 496 (1941); Field, The Abstention Doctrine Today, 125 U. PA. L. Rev. 590 (1977); Field, Abstention in Constitutional Cases: The Scope of the Pullman Abstention Doctrine, 122 U. PA. L. REv. 1071 (1974).

1328 U.S.C. $\$ 2283(1976)$.

14380 U.S. at 489-92 (Pullman abstention inappropriate because statutes so vague and overbroad that no authoritative constitutional construction could be reached in single case and because prosecutions were allegedly threatened in bad faith for harassment purposes).

is Id. at $496 \mathrm{n} .13$ (reading prosecutor's brief to concede that renewed prosecution was threatened under statute on which indictments had been based and remanding for consideration of whether arrests were also made pursuant to the other statute). See also id. at $484 \mathrm{n} .2$ (implying that facts underlying prosecutor's concession were barely sufficient).

"Id. at 484 n.2; see Warren, Federal and State Court Interference, 43 Harv. L. REv. 345, 366-78 (1930); Note, Federal Power to Enjoin State Court Proceedings, 74 HARv. L. REv. 726, 728-29 (1961).

${ }_{17}$ This holding is criticized in Fiss, Dombrowski, 86 YaLE L.J. 1103, 1109-10 (1977).

18380 U.S. at 484 n.2.

"See generally O. Fiss, The Civil Rughts Injunction (1978); Laycock, Book Review, 
argued that the plaintiffs' defense to the state prosecution would be an adequate legal remedy, making federal equity relief unnecessary. The plaintiffs argued that the state remedy was inadequate to protect their first amendment freedoms. The Court began its analysis by noting that Ex parte Young-which it called "the fountainhead of federal injunctions against state prosecutions"20_had made relief generally available to citizens threatened with prosecution under allegedly unconstitutional laws. The Court went on to say, however, that since Young, "considerations of federalism have tempered the exercise of equitable power, for the Court has recognized that federal interference with a state's good-faith administration of its criminal laws is peculiarly inconsistent with our federal framework."2t The Court then cited Douglas $v$. City of Jeannette ${ }^{22}$ and four earlier cases $^{23}$ in which injunctions had been denied to support the proposition that "[i]t is generally to be assumed that state courts and prosecutors will observe constitutional limitations as expounded by this Court, and that the mere possibility of erroneous initial application of constitutional standards will usually not amount to the irreparable injury necessary to justify a disruption of orderly state proceedings."24

The Court's review of the relevant precedents ended with Douglas. If anything had happened to cast doubt on the proposition that federalism concerns substantially restricted the availability of prospective relief, the opinion gave no hint of it. The Court proceeded, however, to announce an exception to the Douglas rule for injunctions against the enforcement of overbroad regulation of speech. "Because of the sensitive nature of constitutionally protected expression," 25 and because numerous prosecutions would be required to work out the constitutional limits of an overbroad statute, defense of a criminal prosecution was not an adequate remedy, and injunctive relief was therefore appropriate. This exception was obviously important, especially to the civil rights and antiwar movements of the sixties. Because marches and demonstrations were among the principal weapons of these movements, many of their

TExas L. Rev. (forthcoming) (1979).

20380 U.S. at 483.

21 Id. at 484 (footnote omitted).

2319 U.S. 157 (1943).

23 Watson v. Buck, 313 U.S. 387 (1941); Beal v. Missouri Pac. R.R., 312 U.S. 45 (1941); Spielman Motor Sales Co. v. Dodge, 295 U.S. 89 (1935); Fenner v. Boykin, 271 U.S. 240 (1927).

380 U.S. at $484-85$.

${ }^{25}$ Id. at 486. 
legal battles raised overbreadth issues. Moreover, a wide range of official conduct could be portrayed as restricting or inhibiting protected speech and thus brought within the Dombrowski exception by analogy. ${ }^{26}$ If Douglas were indeed the controlling precedent, an overbreadth exception would have been a major victory for the activist movements.

Commentators have almost uniformly viewed Dombrowski as such a victory. ${ }^{27}$ Professor Sedler found Dombrowski "an extremely important change," for it meant "that frequently federal rights can be vindicated in the federal district courts." 28 To Dean Stickgold, Dombrowski was a "basic policy change from Douglas and other more recent first amendment cases." 29 A few commentators disagreed, at least in part, ${ }^{30}$ but their compilations of pre-Dombrowski

${ }^{28}$ See, e.g., Sobol v. Perez, 289 F. Supp. 392 (E.D. La. 1968); Chandler v. Garrison, 286 F. Supp. 191 (E.D. La. 1968); Holt v. Richmond Redev. \& Hous. Auth., 266 F. Supp. 397 (E.D. Va. 1966).

27 Bailey, Enjoining State Criminal Prosecutions Which Abridge First Amendment Freedoms, 3 HaRv. C.R.-C.L.L. REv. 67, 69-91 (1967); Boyer, Federal Injunctive Relief Against the Use of State Criminal Prosecutions Designed to Deter the Exercise of Preferred Constitutional Rights, 13 How. L. Rev. 51, 83-85 (1967); Brewer, Dombrowski v. Pfister: Federal Injunctions Against State Prosecutions in Civil Rights Cases-A New Trend in Federal-State Judicial Relations, 34 FordhaM L. REv. 71, 72-73, 83-86 (1965); Fiss, supra note 17, at 1103-17, 1163-64; Kanowitz, Deciding Federal Law Issues in Civil Proceedings: State Versus Federal Trial Courts, 3 Hastings Const. L.Q. 141, 166 (1976); Sedler, The Dombrowski-Type Suit as an Effective Weapon for Social Change: Reflections from Without and Within, 18 U. KaN. L. REv. 237, 244-45, 253-58 (1970); Stickgold, Variations on the Theme of Dombrowski v. Pfister: Federal Intervention in State Criminal Proceedings Affecting First Amendment Rights, 1968 Wis. L. Rev. 369, 380-85; The Supreme Court, 1970 Term, 85 Harv. L. Rev. 38, 301-02 (1971); The Supreme Court, 1964 Term, 79 Harv. L. Rev. 56, 170-74 (1965); Note, Constitutional Law: Limitations Imposed on Traditional Use of Doctrine of Federal Judicial Abstention, 1966 Duke L.J. 219; Comment, Federal Injunctions Against State Actions, 35 GEo. WASH. L. REv. 744, 801-04 (1967); Note, HUAC and the "Chilling Effect": The Dombrowski Rationale Applied, 21 RuTGERs L. REv. 679, 693-95 (1967); Note, The Dombrowski Remedy-Federal Injunctions Against State Court Proceedings Violative of Constitutional Rights, 21 RuTGers L. Rev. 92, 122-24 (1966); Note, Constitutional Law-Injunction Against State Prosecution of Statutes Attacked for Vagueness, 32 TENN. L. Rev. 641 (1965); Comment, Power to Enjoin Prosecutions Violative of Federally Protected Rights, 114 U. PA. L. Rev. 561, 563-64 (1966).

${ }^{28}$ Sedler, supra note 27, at 254.

20 Stickgold, supra note 27, at 383 (footnotes omitted).

30 Wechsler, Federal Courts, State Criminal Law, and the First Amendment, 49 N.Y.U.L. REv. 740 (1974) (cases denying prospective relief were aberrations, and Dombrowski a slight retrenchment, but nonetheless a "constitutional watershed" for articulating first amendment values at stake). See also Maraist, Federal Injunctive Relief Against State Court Proceedings: The Significance of Dombrowski, 48 TEx. L. REv. 535, 548-52 (1970) (Dombrowski part of a "civil rights exception" to Douglas, created by lower courts and impliedly approved by earlier Supreme Court decisions); Whitten, Federal Declaratory and Injunctive Interference with State Court Proceedings: The Supreme Court and the Limits of Judicial Discretion, 53 N.C.L. REv. 591, 635-37 (1975) (Dombrowski part of a period of "loose restraint"). 
cases granting injunctions do not appear to have had significant influence on the prevailing view. ${ }^{31}$ In a recent leading article, Professor Fiss wrote of Dombrowski's "revolutionary promise . . . to open the doors that had long been kept shut by Douglas." 32

These views rely, of course, on Dombrowski's statements regarding prior doctrine. A detailed review of the pre-Dombrowski precedents indicates that this reliance is misplaced.

\section{The Pre-Dombrowski Precedents}

\section{A. Young to Douglas}

1. The Young Dilemma. Ex parte Young provided the first detailed analysis of the inadequacy of the criminal defense as a remedy for persons subject to an unconstitutional statute. ${ }^{33}$ That remedy left the citizen in a dilemma: he could comply with the law and forgo his allegedly constitutional conduct, or defy the law and test its validity in a criminal case at the risk of criminal penalties of his constitutional claim were rejected. The need to make this choice, which will be referred to as the Young dilemma, can be eliminated only if the citizen is permitted to secure a judicial decision on his constitutional claim before engaging in the conduct the statute seeks to proscribe.

Providing relief from the Young dilemma has been at the heart of legislative and judicial policy in this area throughout the century. ${ }^{34}$ Congress early on made special provision for Young-based injunctions in the Three-Judge Court Act ${ }^{35}$ and later provided an alternative remedy in the Declaratory Judgment Act. ${ }^{36}$ The legislative history of the latter makes clear that Congress accepted the basic premise first elaborated in Young and later championed by Professor Borchard ${ }^{37}$-a person should not have to risk penalties to learn his rights. ${ }^{38}$ More importantly for our purposes, this same

31 See B. Schwartz, Constitutional Law 30-31 (2d ed. 1978); Fiss, supra note 17.

32 Fiss, supra note 17, at 1116.

33209 U.S. at 161-68. Earlier cases are presented in Warren, supra note 16, at 373; Wechsler, supra note 30 , at 743-62.

31 See D. Currie, Federal Courts 746 (2d ed. 1975).

${ }^{35}$ Act of June 18, 1910, ch. $309, \S 17,36$ Stat. 539 , 557 (codified at 28 U.S.C. $\S 2281$ (1970)) (repealed 1976).

${ }^{36} 28$ U.S.C. $\$ \$ 2201-2202$ (1976).

37 E. Borchard, Declaratory Judgments 764-801 (2d ed. 1941); E. Borchard, DeclaraTORY JUDGMENTS 341-49 (1st ed. 1934); Borchard, Challenging "Penal" Statutes by Declaratory Action, 52 YALE L.J. 445 (1943).

${ }^{38}$ H.R. REP. No. 1264, 73d Cong., 2d Sess. (1934); S. Rep. No. 1005, 73d Cong., 2d Sess. (1934). The history of this act is reviewed in Steffel v. Thompson, 415 U.S. 452, 465-68 (1974), 
insight accounts for an almost unbroken line of pre-Dombrowski Supreme Court cases granting prospective relief to persons facing the Young dilemma. ${ }^{39}$

These precedents make little mention of three distinctions that became the focus of sharp debate in the post-Dombrowski era: the distinctions between injunctions and declaratory judgments, ${ }^{40}$ between criminal and civil proceedings, ${ }^{41}$ and between cases with and cases without pending enforcement proceedings. ${ }^{42}$ Indeed, many of the pre-Dombrowski opinions do not state enough facts to permit categorization in terms of these distinctions. Those that do generally involve suits for injunctions ${ }^{43}$ against criminal enforcement proceedings ${ }^{44}$ that are not yet pending. ${ }^{45}$ In terms of the Young dilemma, however, such classifications involve only minor variations on the basic paradigm of citizens seeking prospective relief to avoid the risk of penalties. These variations will not be discussed until the examination of Dombrowski's consequences in Part III.

2. The Douglas Dictum. In the period following Ex parte Young, the Young dilemma was frequently explained, ${ }^{46}$ and the Young remedy even more frequently applied. ${ }^{47}$ From Young to Douglas, the Supreme Court decided by opinion at least ninety-four cases seeking injunctions against enforcement of state statutes. In thirty-three of these cases, the injunction issued. ${ }^{48}$ Forty-two injunc-

and Perez v. Ledesma, 401 U.S. 82, 111-15, 125 n.16 (Brennan, J., concurring in part, dissenting in part).

${ }^{39}$ See text and notes at notes 46-144 infra.

'0 See text and notes at notes 192-199 infra. See also Fiss, supra note 17, at 1121-25, 114360.

"See Fiss, supra note 17, at 1136-38; Note, Younger Grows Older: Equitable Abstention in Civil Proceedings, 50 N.Y.U.L. REv. 870 (1975).

12 See text and notes at notes 200-207 infra. See also Fiss, supra note 17, at 1125-27, 1130 $36,1139-43$.

${ }^{13}$ For an exception, see City of Chicago v. Atchison, T. \& S.F. Ry., 357 U.S. 77 (1958).

" For exceptions, see Stainback v. Mo Hock Ke Lok Po, 336 U.S. 368 (1948) and cases cited in Wechsler, supra note 30 , at 795 n.224.

${ }^{45}$ For exceptions, see cases cited in note 201 infra.

'S See cases collected in Laycock, supra note 5, at 197 n.32.

17 More detailed reviews of this period may be found in Soifer \& MacGill, The Younger Doctrine: Reconstructing Reconstruction, 55 Tex. L. Rev. 1141, 1148-63 (1977); Wechsler, supra note 30 , at 762-822.

48 Hines v. Davidowitz, 312 U.S. 52 (1941); Hague v. CIO, 307 U.S. 496 (1939); Gibbs v. Buck, 307 U.S. 66 (1939); Hale v. Bimco Trading, Inc. 306 U.S. 375 (1939); Grosjean v. American Press Co., 297 U.S. 233 (1936); Lee v. Bickell, 292 U.S. 415 (1934); Glenn v. Field Packing Co., 290 U.S. 177 (1933); Champlin Ref. Co. v. Corporation Comm'n, 286 U.S. 210 (1932); Cudahy Co. v. Hinkle, 278 U.S. 460 (1929); Williams v. Standard Oil Co., 278 U.S. 235 (1929); Hopkins v. Southern Cal. Tel. Co., 275 U.S. 393 (1928); Cline v. Frink Dairy Co., 274 U.S. 445 (1927); Tyson \& Brother v. Banton, 273 U.S. 418 (1927); Farrington v. Tokushige, 273 U.S. 284 (1927); Weaver v. Palmer Bros., 270 U.S. 402 (1926); Connally v. General 
tions were denied on the merits, ${ }^{49}$ and six cases were remanded for further factual development. ${ }^{50}$ Because the federal court decided the constitutional merits under each of these dispositions, each is inconsistent with the view that the merits should be left to state courts in enforcement proceedings. Another six cases were dismissed for procedural reasons, ${ }^{51}$ and two because plaintiff faced no risk of prosecution. ${ }^{52}$

Constr. Co., 269 U.S. 385 (1926); Pierce v. Society of Sisters, 268 U.S. 510 (1925); Real Silk Mills v. Portland, 268 U.S. 325 (1925); Shafer v. Farmers Grain Co., 268 U.S. 189 (1925); Michigan Pub. Utils. Comm'n v. Duke, 266 U.S. 570 (1925); Ozark Pipe Line Corp. v. Monier, 266 U.S. 555 (1925); Air-Way Corp. v. Day, 266 U.S. 71 (1924); Lemke v. Farmers Grain Co., 258 U.S. 50 (1922); Dawson v. Kentucky Distilleries \& Warehouse Co., 255 U.S. 288 (1921); Oklahoma Operating Co. v. Love, 252 U.S. 331 (1920); Truax v. Raich, 239 U.S. 33 (1915); Bacon v. Rutland R.R., 232 U.S. 134 (1914); Adams Express Co. v. New York, 232 U.S. 14 (1914); Missouri Rate Cases, 230 U.S. 474 (1913); Minnesota Rate Cases, 230 U.S. 352 (1913); Herndon v. Chicago, R.I. \& Pac. Ry., 218 U.S. 135 (1910); Ludwig v. Western Union Tel. Co., 216 U.S. 146 (1910); Ex parte Young, 209 U.S. 123 (1908).

" Parker v. Brown, 317 U.S. 341 (1943); Reitz v. Mealey, 314 U.S. 33 (1941); Minersville School Dist. v. Gobitis, 310 U.S. 586 (1940); Ziffrin, Inc. v. Reeves, 308 U.S. 132 (1939); Mahoney v. Joseph Triner Corp., 304 U.S. 401 (1938); Henderson Co. v. Thompson, 300 U.S. 258 (1937); State Bd. of Equalization v. Young's Mkt. Co., 299 U.S. 59 (1936); A. Magnano Co. v. Hamilton, 292 U.S. 40 (1934); State Bd. of Tax Comm'rs v. Jackson, 283 U.S. 527 (1931); Carley \& Hamilton v. Snook, 281 U.S. 66 (1930); Gulf Fisheries Co. v. MacInerney, 276 U.S. 124 (1928); Interstate Busses Corp. v. Holyoke Ry., 273 U.S. 45 (1927); Village of Euclid v. Ambler Realty Co., 272 U.S. 365 (1926); Hygrade Provision Co. v. Sherman, 266 U.S. 497 (1925); Dillingham v. McLaughlin, 264 U.S. 370 (1924); Packard v. Banton, 264 U.S. 140 (1924); Frick v. Webb, 263 U.S. 326 (1923); Porterfield v. Webb, 263 U.S. 225 (1923); Terrace v. Thompson, 263 U.S. 197 (1923); Oliver Iron Co. v. Lord, 262 U.S. 172 (1923); Douglas v. Noble, 261 U.S. 165 (1923); Bratton v. Chandler, 260 U.S. 110 (1922); Walls v. Midland Carbon Co., 254 U.S. 300 (1920); Hebe Co. v. Shaw, 248 U.S. 297 (1919); Van Dyke v. Geary, 244 U.S. 39 (1917); Merrick v. Halsey \& Co., 242 U.S. 568 (1917); Caldwell v. Sioux Falls Stock Yards Co., 242 U.S. 559 (1917); Hall v. Geiger-Jones Co., 242 U.S. 539 (1917); McNaughton v. Johnson, 242 U.S. 344 (1917); Crane v. Johnson, 242 U.S. 339 (1917); Tanner v. Little, 240 U.S. 369 (1916); Rast v. Van Deman \& Lewis Co., 240 U.S. 342 (1916); Northwestern Laundry v. City of Des Moines, 239 U.S. 486 (1916); Mutual Film Corp. v. Industrial Comm'n, 236 U.S. 230 (1915); Ohio Tax Cases, 232 U.S. 576 (1914); Allen v. St. Louis, I.M. \& S. Ry., 230 U.S. 553 (1913); Southern Pac. Co. v. Campbell, 230 U.S. 537 (1913); Oregon R.R. \& Navigation Co. v. Campbell, 230 U.S. 525 (1913); Chesapeake \& O. Ry. v. Conley, 230 U.S. 513 (1913); Hampton v. St. Louis, I.M. \& S. Ry., 227 U.S. 456 (1913); Savage v. Jones, 225 U.S. 501 (1912); Lindsley v. National Carbonic Gas Co., 220 U.S. 61 (1911). See also Massachusetts State Grange v. Benton, 272 U.S. 525, 527 (1926) (alternative holding).

so Polk Co. v. Glover, 305 U.S. 5 (1938); Borden's Farm Prods. Co. v. Baldwin, 293 U.S. 194 (1934); Oklahoma Gas Co. v. Russell, 261 U.S. 290 (1923); Detroit United Ry. v. City of Detroit, 248 U.S. 429 (1919); Home Tel. \& Tel. Co. v. City of Los Angeles, 227 U.S. 278 (1913); Western Union Tel. Co. v. Andrews, 216 U.S. 165 (1910).

s1 Premier-Pabst Sales Co. v. Grosscup, 298 U.S. 226 (1936) (plaintiff lacked standing); Healy v. Ratta, 292 U.S. 263 (1934) (insufficient amount in controversy); Gilchrist v. Interborough Rapid Transit Co., 279 U.S. 159 (1928) (exhaustion of state remedies required in rate cases); Henderson Water Co. v. Corporation Comm'n, 269 U.S. 278 (1925) (same); Pullman Co. v. Croom, 231 U.S. 571 (1913) (appeal abated by death of party); Prentis v. Atlantic Coast Line, 211 U.S. 210 (1908) (exhaustion of state remedies required in rate cases).

${ }^{s 2}$ Moor v. Texas \& N.O.R.R., 297 U.S. 101 (1936) (shipper sought injunction ordering 
The remaining five cases are the five Dombrowski cited to illustrate the "rule" that cases seeking such injunctions should normally be dismissed without reaching the merits because a state enforcement proceeding would provide an adequate remedy. Although the language of the five cases-which will be referred to as the Douglas dictum-strongly suggests such a rule, ${ }^{53}$ none of the cases squarely so holds. ${ }^{54}$ Spielman Motor Sales Co. v. Dodge $e^{55}$ comes the closest, but is limited by the Court's reliance on the plaintiff's failure to allege how it would be injured by compliance or to dispute the prosecutor's avowed intention to bring only a single test prosecution. ${ }^{56}$ Fenner $v$. Boykin ${ }^{57}$ actually affirmed a decision on the merits of a motion for preliminary injunction. In Beal v. Missouri Pacific Railroad, ${ }^{58}$ a diversity case in which the railroad alleged that a concededly constitutional statute was being misconstrued by a state prosecutor, the Court emphasized that only a state court could authoritatively resolve the controversy and that the state had promised it would bring only a single test prosecution. Watson $v$. Buck ${ }^{59}$ held prospective relief unavailable with respect to some sections of the challenged statute, but reached the merits of the plaintiff's challenge to the most important section without explaining why it was different from the others. Finally, in Douglas v. City of Jeannette ${ }^{60}$ the plaintiffs were not required to risk further penalties to exercise their first amendment rights because the challenged ordinance was held unconstitutional in the companion case of Murdock v. Pennsylvania ${ }^{61}$ Since there was no reason to believe that the state prosecutor and courts would not adhere to the Court's ruling in Murdock, the plaintiffs no longer faced the Young dilemma, prospective relief was unnecessary, and federal interference inappropriate..$^{62}$

railroad to violate statute regulating railroad); Massachusetts State Grange v. Benton, 272 U.S. 525, 527-29 (1926) (no penalty for violation of statute) (alternative holding; statute also sustained, on merits).

${ }^{53}$ Cf. Hynes v. Grimes Packing Co., 337 U.S. 86, 98-100 (1949) (stating "rule" that injunctions against federal prosecution normally will not issue, but authorizing injunction on routine showing of Young dilemma); Wechsler, supra note 30, at 784-85 (noting that, even after exception swallowed rule, pre-Douglas Court often described relief from Young dilemma as exception to general rule forbidding prospective relief).

st See D. CuRRIE, supra note 34, at 746-48.

55295 U.S. 89 (1935).

${ }^{38}$ On the problems with such promises, see Laycock, supra note 5, at 211-12.

s7 271 U.S. 240 (1926).

sx 312 U.S. 45 (1941).

313 U.S. 387 (1941).

${ }^{60} 319$ U.S. 157 (1943).

s1 319 U.S. 105 (1943).

62319 U.S. at 165. 
These are the five cases that Dombrowski maintained had substantially modified Young and its scores of uncited progeny. If Young had been modified, one would expect to find that injunctive relief became relatively unavailable in the years following Douglas. But this is not what happened.

\section{B. The Forgotten Precedents}

1. The Battle over Douglas. Even in the early forties, the dominant line of cases freely granting injunctions did not die out. On the day that Beal was decided, the Court enjoined enforcement of a state alien registration law without making any reference to Beal or suggesting that any special showing of the need for prospective relief was required or had been made. ${ }^{63}$ Between Watson v. Buck and Douglas, two requests for injunctions against state enforcement proceedings were denied on the merits. The first case ${ }^{64}$ did not refer to the remedies issue, but in the second, ${ }^{65}$ the Court summarily rejected the defendants' contention that the plaintiff's opportunity to raise his constitutional claim as a defense in the enforcement proceeding afforded him an adequate remedy. ${ }^{66}$

Following Douglas, the Court continued to give conflicting signals. In West Virginia State Board of Education v. Barnette, ${ }^{67}$ it enjoined state enforcement proceedings without making any reference to the Douglas line of cases. Another opinion referred to "the traditional use of equity proceedings to enjoin criminal proceedings." 68 But in three other opinions, the Douglas dictum was restated, each time in sweeping terms and in further dictum. ${ }^{69}$ Douglas was also cited as an alternative ground for decision in one affirmance without opinion..$^{70}$ These conflicting indications apparently represented real division on the Court. Although the Douglas dictum appeared six times in the early forties, all of these opinions were written by only two Justices: two were written by Justice Black $^{71}$ and four, including Douglas itself, by Chief Justice Stone. ${ }^{72}$

w Hines v. Davidowitz, 312 U.S. 52 (1941).

u Reitz v. Mealey, 314 U.S. 33 (1941).

4s Parker v. Brown, 317 U.S. 341 (1943).

" Id. at 349-50.

17319 U.S. 624 (1943).

* Switchmen's Union v. National Mediation Bd., 320 U.S. 297, 306 (1943).

" Yakus v. United States, 321 U.S. 414, 444 (1944); Meredith v. Winter Haven, 320 U.S. 228, 235 (1943); Burford v. Sun Oil Co., 319 U.S. 315, 333 n.29 (1943).

70 Ryan v. Thompson, 324 U.S. 821 (1945).

7 Burford v. Sun Oil Co., 319 U.S. 315, 333 n.29 (1943); Watson y. Buck, 313 U.S. 387, 400-02 (1941). But see Hines v. Davidowitz, 312 U.S. 52 (1941) (Black, J., for the Court) 
This division came into the open and was resolved against the Douglas dictum in $A F L v$. Watson, ${ }^{73}$ a result reinforced two years later-after Chief Justice Stone's death-by a unanimous Court in Toomer $v$. Witsell. ${ }^{74}$

In $A F L \quad v$. Watson, various unions and employers sought to enjoin civil and criminal enforcement of a right-to-work amendment to the Florida constitution. The Court responded with a two-part holding. First, it held that the plaintiffs had alleged sufficient irreparable injury to justify prospective relief. It then ordered Pullman abstention, directing the district court to retain jurisdiction and indicating that that court was free to issue preliminary injunctions. ${ }^{75}$ The Court seemed to contemplate that most prosecutions would be enjoined while the state-law questions were resolved in one or more test cases. ${ }^{76}$

Chief Justice Stone's solitary dissent squarely posed the Douglas issue. He acknowledged the full implications of the dictum, reading it to mean that forfeiture of rights because of fear of prosecution was a wrong without a remedy and no basis for an injunction against enforcement. ${ }^{77}$ The Watson majority clearly did not accept Chief Justice Stone's view. The majority opinion quoted Douglas on the need for "irreparable injury which is clear and imminent," and called this "a strict test." 78 But it did not quote any of the key sentences about enforcement proceedings providing adequate remedies. ${ }^{79}$ More importantly, Watson's reasoning was fundamentally inconsistent with Douglas. The Douglas dictum had focused on the consequences of the plaintiff's violation of the challenged law: violation would bring prosecution and an adjudication of the constitutional issue. The majority in Watson focused instead on the conse-

(enjoining enforcement of state alien registration law).

${ }^{72}$ Yakus v. United States, 321 U.S. 414, 444 (1944); Meredith v. Winter Haven, 320 U.S. 228, 235 (1943); Douglas v. City of Jeannette, 319 U.S. 157, 162-63 (1943); Beal v. Missouri Pac. R.R., 312 U.S. 45, 49-51 (1941). But see Parker v. Brown, 317 U.S. 341, 349-50 (1943) (Stone, C.J., for the Court) ("The majority of the Court is also of opinion that the suit is within the equity jurisdiction of the Court since the complaint alleges and the evidence shows threatened irreparable injury to respondent's business").

73327 U.S. 582 (1946).

3334 U.S. 385 (1948).

${ }^{75} 327$ U.S. at 595 n.10; accord, Babbitt v. UFW, 99 S. Ct. 2301, 2316 n.18 (1979); Harrison v. NAACP, 360 U.S. 167, 178-79 (1959).

7627 U.S. at 599.

"Id. at 600 (Stone, C.J., dissenting). See also Yakus v. United States, 321 U.S. 414, 444 (1944) (Stone, C.J.) (dictum) (validity of most penal statutes "can be determined only by running the risk of violation").

7x 327 U.S. at 593.

"Id. 
quences of compliance. Compliance would cause injuries that could not be measured in money: "disruption in collective bargaining . . . loss in bargaining position . . . decrease in union membership." "80 Since the cost of compliance could not be measured in money, no legal remedy was adequate.

This focus on compliance makes sense only in terms of the Young dilemma, while Douglas's focus on violation would make sense only if the Young dilemma did not exist. Douglas ignored the uncertainty that gives rise to the Young dilemma. Its approach would be sound only if every citizen were so confident in his constitutional judgment that he would risk penalties by violating invalid statutes and so accurate that he would never actually incur penalties by violating valid ones. In contrast, the argument of the Watson majority-that citizens would forgo their asserted rights despite the resulting irreparable injury-assumes that the risk of penalties would be a deterrent. It pointed to the existing threats of prosecution only to show the reality of the risk that induced compliance; defense of such prosecutions was not a potential remedy..$^{82}$ In short, Watson treated the Young dilemma as very real indeed and gave relief accordingly.

Toomer $v$. Witsell ${ }^{83}$ completed the restoration of Ex parte Young. In Toomer, plaintiffs sought to enjoin enforcement of South Carolina laws requiring out-of-state fishermen either to pay local taxes and license fees and use South Carolina port facilities or to stay out of South Carolina waters. A unanimous Court rejected the defendants' argument ${ }^{84}$ that the Douglas line of cases barred prospective relief:

It is also clear that compliance . . . would have required payment of large sums of money for which South Carolina provides no means of recovery, that defiance would have carried with it the risk of heavy fines and long imprisonment, and that withdrawal from further fishing until a test case had been taken through the. South Carolina courts and perhaps to this Court would have resulted in a substantial loss of business for which no compensation could be obtained. ${ }^{85}$

Id. at 594 .

"Id. at 595 .

${ }^{22}$ See id. at $594 \mathrm{n} .9$ ("The inadequacy of relief at law is measured by the character of the relief afforded by the federal not the state courts.").

* 334 U.S. 385 (1948).

* Brief for Appellees at 22, Toomer v. Witsell, 334 U.S. 385 (1948).

334 U.S. at 391-92. 
This is a straightforward description of the Young dilemma. The two alternatives to risking penalties-paying fees or withdrawing from South Carolina waters-were merely alternative means of compliance. Toomer thus went beyond Watson in two ways. First, the risk-of-penalties branch of the Young dilemma was once again made explicit. Second, it held that even when the cost of compliance can be measured in money, the legal remedy is inadequate unless the state has waived its immunity from suit. This holding was important since few states were likely to acknowledge liability for consequential damages caused by compliance with invalid statutes.

There are few prospective challenges to statutes that could not be brought under the Toomer standard. Its analysis of the Young dilemma would apply to any statute carrying penalties, for compliance always costs something and defiance is never risk-free. Conceivably, the decision leaves room for a line-drawing argument: a statute with only token penalties might be distinguished from the "heavy fines and long imprisonment" referred to in Toomer. ${ }^{86}$ But no such argument emerged in the later case law; to the contrary, the Court subsequently entertained a prospective challenge to a statute carrying a $\$ 100$ fine $^{87}$ and indicated a willingness to decide, after Pullman abstention, a prospective challenge to a statute imposing a $\$ 4$ fine ${ }^{88}$ These are the correct results in light of the Young dilemma. No penalty is token when multiplied by sufficient offenses, and most plaintiffs seeking prospective relief are engaged in continuing conduct involving repeated violation. ${ }^{89}$ Moreover, any criminal conviction carries a stigma that adds to the deterrent effect of the stated penalty. Accordingly, any line-drawing argument would be spurious. Nor were Toomer's implications limited by its dismissal of the plaintiffs' challenge to the South Carolina income tax. ${ }^{80}$ The plaintiffs could pay under protest and sue in the state court for a refund. That remedy did not expose the plaintiffs to any risk of penalties, and the Tax Injunction Act ${ }^{91}$ required them to use

"Id. at 392.

*7 Two Guys, Inc. v. McGinley, 366 U.S. 582, 589 (1961).

* Id. at 585-86, 589. See also Ex parte Young, 209 U.S. 123 (1908); id. at 171-72 (Harlan, J., dissenting) (prosecutor's promise to bring only a single mandamus proceeding to compel compliance until constitutional issue resolved treated as irrelevant by majority). But see Beal v. Missouri Pac. R.R., 312 U.S. 45, 50 (1941); Spielman Motor Sales Co. v. Dodge, 295 U.S. 89, 96 (1935).

xs See Laycock, supra note 5, at 207.

90 334 U.S. at 392.

ง 28 U.S.C. $\$ 1341$ (1976). 
it. In short, Toomer's reasoning fully repudiates the Douglas dictum. Its only ambiguity is that this consequence was left implicit: Douglas was not cited.

2. Irreparable Injury after Toomer. After AFL $v$. Watson and Toomer, injunctions against threatened enforcement of state statutes again issued routinely. In the twenty-two years from Douglas to Dombrowski, the Court ordered or affirmed at least fifty-six district court injunctions or declaratory judgments preventing enforcement of state constitutions, statutes, or local ordinances. To be sure, many of these laws - those relating to voting rights, ${ }^{92}$ school administration, ${ }^{93}$ and public employment ${ }^{94}$-would not ordinarily have been enforced by judicial proceedings, so that Douglas was not directly implicated. Moreover, those in which the United States was the plaintiffos can perhaps be explained away as special treatment for the sovereign, ${ }^{96}$ even though the Court itself has never offered such an explanation. There remain, however, twenty-one cases in which the Court enjoined state enforcement proceedings against

12 Louisiana v. United States, 380 U.S. 145 (1965); Tancil v. Woolls, 379 U.S. 19, aff'g mem., Hamm v. Virginia State Bd. of Elections, 230 F. Supp. 156 (E.D. Va. 1964); Hill v. Davis, 378 U.S. 565 (1964); Pinney v. Butterworth, 378 U.S. 564 (1964); Williams v. Moss, 378 U.S. 558 (1964); Meyers v. Thigpen, 378 U.S. 554 (1964); Lucas v. Forty-Fourth Gen. Assembly, 377 U.S. 713 (1964); Roman v. Sincock, 377 U.S. 695 (1964); Davis v. Mann, 377 U.S. 678 (1964); Maryland Comm. for Fair Representation v. Tawes, 377 U.S. 656 (1964); WMCA, Inc. v. Lomenzo, 377 U.S. 633 (1964); Reynolds v. Sims, 377 U.S. 533 (1964); Martin v. Bush, 376 U.S. 222 (1964); Wesberry v. Sanders, 376 U.S. 1 (1964); Anderson v. Martin, 375 U.S. 399 (1964); Gray v. Sanders, 372 U.S. 368 (1963); Gomillion v. Lightfoot, 364 U.S. 339 (1960); Schnell v. Davis, 336 U.S. 933, aff'g mem., 81 F. Supp. 872 (S.D. Ala. 1949).

${ }^{3}$ Griffin v. County School Bd., 377 U.S. 218 (1964); Abington School Dist. v. Schempp, 374 U.S. 203 (1963); St. Helena Parish School Bd. v. Hall, 368 U.S. 515 (1962), aff'g mem., 197 F. Supp. 649 (E.D. La. 1961); Legislature of La. v. United States, 367 U.S. 908, aff'g mem., Bush v. Orleans Parish School Bd., 191 F. Supp. 871 (E.D. La. 1961); Orleans Parish School Bd. v. Bush, 365 U.S. 569 (1961), aff'g mem., 188 F. Supp. 916 and 187 F. Supp. 42 (E.D. La. 1960); Bush v. Orleans Parish School Bd., 364 U.S. 500 (1960); Faubus v. Aaron, 361 U.S. 197, aff'g mem., Aaron v. McKinley, 173 F. Supp. 944 (E.D. Ark. 1959); State Athletic Comm'n v. Dorsey, 359 U.S. 533 (1959), aff'g mem., 168 F. Supp. 149 (E.D. La. 1958); Cooper v. Aaron, 358 U.S. 1 (1958); Brown v. Board of Educ., 347 U.S. 483 (1954); McLaurin v. Oklahoma State Regents, 339 U.S. 637 (1950).

" Baggett v. Bullitt, 377 U.S. 360 (1964); Shelton v. Tucker, 364 U.S. 479 (1960).

Is Paul v. United States, 371 U.S. 245 (1963); Lassiter v. United States, 371 U.S. 10 (1963), aff'g mem., 203 F. Supp. 20 (W.D. La. 1962); Public Util. Comm'n v. United States, 355 U.S. 534 (1958); Mayo v. United States, 319 U.S. 441 (1943).

" See First Fed. Sav. \& Loan Ass'n v. Greenwald, 591 F.2d 417 (1st Cir. 1979) (United States exempt from requirements of Younger $v$. Harris); cf. Leiter Minerals, Inc. v. United States, 352 U.S. 220, 224-26 (1957) (United States exempt from Anti-Injunction Act); United States v. UMW, 330 U.S. 258, 269-89 (1947) (United States exempt from Norris-LaGuardia Act) (alternative holding); United States v. Texas, 143 U.S. 621, 644-45 (1892) (United States exempt from sovereign-immunity defense). But cf. Leiter Minerals, Inc. v. United States, 352 U.S. 220, 228-30 (1957) (United States not exempt from Pullman abstention). 
federal plaintiffs or prevented such proceedings by declaring the statute invalid. This latter group of cases was not merely, as one commentator has suggested, ${ }^{97}$ a civil rights exception to Douglas. Ten cases did involve racial discrimination, ${ }^{98}$ and one was a free speech case.$^{98}$ But nine struck down economic regulation ${ }^{100}$ and one voided a state tax. ${ }^{101}$ Moreover, there were at least sixteen additional cases in which the Court failed to grant prospective relief for reasons other than irreparable injury-cases in which, contrary to the Douglas dictum, the Court resolved the constitutional merits ${ }^{102}$ or authorized their resolution in federal court on remand. ${ }^{103}$

Although the Court did not discuss the irreparable injury issue at length after Toomer, it alluded to it or closely related issues with sufficient frequency to negate any argument that the requirement was simply overlooked for two decades. In Spector Motor Service, Inc. $v$. $O^{\prime}$ Connor, ${ }^{104}$ for example, the Court applied traditional irreparable injury doctrine without mentioning Douglas. The Court enjoined collection of a state income tax despite the Tax Injunction Act ${ }^{105}$ and a newly created state remedy, invoking the old equity rule

${ }_{97}$ Maraist, supra note 30 , at 548-52.

${ }^{98}$ City of New Orleans v. Barthe, 376 U.S. 189 (1964), aff'g mem., 219 F. Supp. 788 (E.D. La. 1963); Watson v. City of Memphis, 373 U.S. 526 (1963); Turner v. City of Memphis, 369 U.S. 350 (1962); Bailey v. Patterson, 369 U.S. 31 (1962); Gremillion v. United States, 368 U.S. 11, aff'g mem., Bush v. Orleans Parish School Bd., 194 F. Supp. 182 (E.D. La. 1961); Tugwell v..Bush, 367 U.S. 907, aff'g mem., Bush v. Orleans Parish School Bd., 194 F. Supp. 182 (E.D. La. 1961); Louisiana ex rel. Gremillion v. NAACP, 366 U.S. 293 (1961); Gayle v. Browder, 352 U.S. 903, aff'g mem., 142 F. Supp. 707 (M.D. Ala. 1956); Holmes v. City of Atlanta, 350 U.S. 879, vacating mem., 223 F.2d 93 (5th Cir. 1955); Mayor of Baltimore City v. Dawson, 350 U.S. 877, aff'g mem., 220 F.2d 386 (4th Cir. 1955).

29 West Virginia State Bd. of Educ. v. Barnette, 319 U.S. 624 (1943).

100 Department of Alcoholic Beverage Control v. Ammex Warehouse Co., 378 U.S. 124 (1964), aff'g mem., 224 F. Supp. 546 (S.D. Cal. 1963); Hostetter v. Idlewild Bon Voyage Liquor Corp., 377 U.S. 324 (1964); Polar Ice Cream \& Creamery Co. v. Andrews, 375 U.S. 361 (1964); Campbell v. Hussey, 368 U.S. 297 (1961); Bibb v. Navajo Freight Lines, Inc., 359 U.S. 520 (1959); City of Chicago v. Atchison, T. \& S.F. Ry., 357 U.S. 77 (1958); Morey v. Doud, 354 U.S. 457 (1957); Toomer v. Witsell, 334 U.S. 385 (1948); Rice v. Santa Fe Elevator Corp., 331 U.S. 218 (1947).

tal Spector Motor Serv., Inc. v. O'Connor, 340 U.S. 602 (1951).

${ }_{102}$ Ferguson v. Skrupa, 372 U.S. 726 (1963); Gallagher v. Crown Kosher Super Mkt., Inc., 366 U.S. 617 (1961); Braunfeld v. Brown, 366 U.S. 599 (1961); Two Guys, Inc. v. McGinley, 366 U.S. 582 (1961); Times Film Corp. v. City of Chicago, 365 U.S. 43 (1961); Williamson v. Lee Optical, Inc., 348 U.S. 483 (1955); Daniel v. Family Security Life Ins. Co., 336 U.S. 220 (1949); Goesaert v. Cleary, 335 U.S. 464 (1948).

${ }^{103}$ England v. Louisiana State Bd. of Medical Examiners, 375 U.S. 411 (1964); Florida Lime \& Avocado Growers, Inc. v. Paul, 373 U.S. 132 (1963); Idlewild Bon Voyage Liquor Corp. v. Epstein, 370 U.S. 713 (1962); Florida Lime \& Avocado Growers, Inc. v. Jacobsen, 362 U.S. 73 (1960); Harrison v. NAACP, 360 U.S. 167 (1959) (after Pullman abstention); Evers v. Dwyer, 358 U.S. 202 (1958); Doud v. Hodge, 350 U.S. 485 (1956); AFL v. Watson, 327 U.S. 582 (1946) (after Pullman abstention).

104 340 Ủ.S. 602 (1951).

${ }^{105} 28$ U.S.C. $\$ 1341$ (1976). See generally Comment, The Tax Injunction Act and Suits 
that legal remedies that first become available after the equity suit is filed are irrelevant to the irreparable injury question. ${ }^{106}$ In Doud $v$. Hodge, ${ }^{107}$ the district court held that it lacked jurisdiction over a suit for prospective relief. ${ }^{108}$ The Supreme Court reversed. On remand, the district court enjoined enforcement of the statute, noting the risk of penalties and cost of compliance, and relying on Toomer v. Witsell. ${ }^{109}$ The Supreme Court affirmed, finding the irreparable injury argument "adequately disposed of in the opinion of the District Court."110

In Evers $v$. Dwyer, "'1' a black plaintiff had been threatened with arrest for sitting in the front of a bus. He left the bus to avoid arrest and then sued to enjoin enforcement of the statute requiring him to sit in the rear. The district court dismissed for want of an actual controversy, but the Supreme Court reversed, saying that the plaintiff need not risk arrest to create a controversy. The irreparable injury issue was not addressed, but the implication for the Douglas dictum was obvious: if the plaintiff need not be arrested to challenge the statute, he need not challenge it in an enforcement proceeding. Evers was so read by the district court in one of the Sunday closing cases, Crown Kosher Super Market, Inc. v. Gallagher. ${ }^{12}$ Although the irreparable injury issue was briefed on appeal in Crown Kosher, ${ }^{113}$ the Supreme Court went directly to the merits without discussing that issue or the district court's treatment of Evers. ${ }^{14}$ One week after Dombrowski, the Court cited Evers as an exception to Douglas's rule against prospective relief. ${ }^{115}$

Part of the irreparable injury issue was addressed in another Sunday closing case, Two Guys, Inc. v. McGinley. ${ }^{116}$ The plaintiff had alleged that the Sunday law established religion and was being discriminatorily enforced by the incumbent prosecutor. A new prosecutor took office, and the plaintiff did not claim that discrimina-

for Monetary Relief, 46 U. CHr. L. Rsv. 736 (1979).

${ }^{106} 340$ U.S. 602, 605 (1951) (citing American Life Ins. Co. v. Stewart, 300 U.S. 203, 215 (1937) and Dawson v. Kentucky Distilleries Co., 255 U.S. 288, 296 (1921)). See Laycock, supra note 5 , at $224-25$.

${ }^{107} 350$ U.S. 485 (1956).

${ }^{10 x}$ Doud v. Hodge, 127 F. Supp. 853 (N.D. Ill. 1955), rev'd, 350 U.S. 485,487 (1956).

${ }^{109}$ Doud v. Hodge, 146 F. Supp. 887, 890 (N.D. IIl. 1956), aff'd sub nom. Morey v. Doud, 354 U.S. 457 (1957).

110354 U.S. 457,470 (1957).

III 358 U.S. 202 (1958).

112176 F. Supp. 466, 471 (D. Mass. 1959), rev'd on the merits, 366 U.S. 617 (1961).

its Brief for Appellants at 38-42, Crown Kosher Super Mkt. Inc. v. Gallagher, 366 U.S.

617 (1961); Brief for Appellees at 25, id.

"1" Gallagher v. Crown Kosher Super Mkt., Inc., 366 U.S. 617 (1961).

113 Zemel v. Rusk, 381 U.S. 1, 19 (1965).

116 366 U.S. 582 (1961). 
tory enforcement would continue. Nevertheless, it denied that its discriminatory enforcement claim was moot, because prosecutions initiated by the former prosecutor were still pending against its employees. The Supreme Court held that defense of those prosecutions was an adequate remedy for the discriminatory enforcement claim, but proceeded to the merits of the establishment claim. ${ }^{117}$ This disposition of the claims is consistent with Toomer and inconsistent with the Douglas dictum. Because nondiscriminatory enforcement could continue, the plaintiff faced the Young dilemma of risking further penalties or forfeiting its establishment clause rights, at least until one of the pending criminal cases was finally decided, ${ }^{118}$ and perhaps longer. ${ }^{119}$ But there was no such dilemma with respect to the discriminatory enforcement claim: the risk of such enforcement was past. Although the Court did not explain how it reached the merits of the establishment claim, its enforcement of the irreparable injury requirement in the context of the discriminatory enforcement claim suggests that that requirement was not overlooked.

Finally, there was the Florida avocado litigation. Plaintiffs challenged a California law prohibiting importation of avocados containing less than eight percent oil, a requirement alleged to have a discriminatory impact on Florida avocados. Avocados were inspected at the state border, and nonconforming shipments were declared a nuisance. The district court originally dismissed the suit because the plaintiffs sold their rejected shipments elsewhere rather than allow them to be seized so that the commerce clause issue could be litigated in a state-court nuisance proceeding. ${ }^{120}$ This sounds like deference to state remedies, but the court described its holding as resting on lack of an actual controversy. The Supreme Court reversed, holding it irrelevant that state remedies had not been tried first. ${ }^{121}$

On remand, the district court expressed its opinion that insufficient irreparable injury had been shown and that Pullman abstention was appropriate. ${ }^{122}$ But it construed the Supreme Court's opinion as requiring it to decide the merits, and it did so, upholding the

${ }^{117}$ Id. at 588-89.

118 See Laycock, supra note 5, at 202-14.

119 See id. at 214-19.

${ }^{120}$ Florida Lime \& Avocado Growers, Inc. v. Jacobsen, 169 F. Supp. 774 (N.D. Cal. 1958), rev'd, 362 U.S. 73 (1960).

121 Florida Lime \& Avocado Growers, Inc. v. Jacobsen, 362 U.S. 73, 85-86 (1960).

${ }_{122}$ Florida Lime \& Avocado Growers, Inc. v. Paul, 197 F. Supp. 780, 784 (N.D. Cal. 1961), rev'd in part, on the merits, 373 U.S. 132 (1963). 
statute. As an alternative ground for affirmance, the state officials argued "that there was insufficient showing of injury to the Florida growers to invoke the district court's equity jurisdiction." ${ }^{23}$ In a second opinion, the Court rejected that contention. It agreed with the district court's reading of its earlier opinion and independently concluded that compliance with the statute by shipping rejected fruit elsewhere would amount to irreparable injury. ${ }^{124}$ On the merits, the Court reversed and remanded for further proceedings.

These opinions, together with the numerous decisions granting prospective relief without raising the issue, strongly suggest that Young and Toomer were the law, and that the Douglas dictum was not. There was no contrary line of cases; the Court did not invoke Douglas to deny prospective relief in some cases and not in others according to a hidden agenda of its own. But neither did it explicitly overrule or limit Douglas. In fact, Douglas continued to be cited from time to time.

Many of these citations to Douglas are plainly irrelevant to the issues here, ${ }^{125}$ but at times the Court cited the dictum as if it were still good law. The most important of these citations appear in a line of cases involving requests for federal injunctions preventing the admission of improperly obtained evidence in state criminal trials. ${ }^{126}$ These cases presented considerations quite different from those of Young and Douglas. In particular, the federal plaintiffs had

123 Florida Lime \& Avocado Growers, Inc. v. Paul, 373 U.S. 132, 157 (1963).

124 Id. at 157-58.

125 Gibson v. Florida Legislative Investigation Comm., 372 U.S. 539, 561 n.2 (1963) (Douglas, J., concurring) (first amendment applies to states); Baker v. Carr, 369 U.S. 186, 200 n.19 (1962) (no jurisdictional amount required under 28 U.S.C. $\$ 1343$ ); Monroe v. Pape, 365 U.S. 167, 171 (1961) (definition of "color of law"); id. at 191 n.50 (overruling Douglas's holding that municipalities can be used under 42 U.S.C. $\$ 1983$ ); id. at 206, 213 n.19 (Frankfurter, J., dissenting in part) (definition of "color of law"); Speiser v. Randall, 357 U.S. 513, 530 (1958) (Black, J., concurring) (first amendment applies to states); American Communications Ass'n v. Douds, 339 U.S. 382, 444 (1950) (Jackson, J., dissenting) (citing his own concurring opinion in Douglas that the first amendment does not immunize "mob movements"); Cassell v. Texas, 339 U.S. 282, 304 (1950) (Jackson, J., dissenting) (racial discrimination in grand jury selection could be remedied by federal injunction); Terminiello v. City of Chicago, 337 U.S. 1, 30 (1949) (Frankfurter, J., dissenting) ("cities may not protect the streets . . . from the aggressions of organized bands"); Railway Express Agency v. New York, 336 U.S. 106, 112 (1949) (Jackson, J., concurring) (citing his own concurring opinion in Douglas that municipal power should not be restricted lightly); Everson v. Board of Educ., 330 U.S. 1, 27 (1947) (Jackson, J., dissenting) (citing his own concurring opinion in Douglas that Court had given unreasonable protection to religion); Thomas v. Collins, 323 U.S. 516, 548 n.l (1945) (Roberts, J., dissenting) (first amendment has been applied); Prince v. Massachusetts, 321 U.S. 158, 177 (1944) (Jackson, J., concurring) (list of Jehovah's Witness cases).

${ }^{126}$ Cleary v. Bolger, 371 U.S. 392, 397 (1963); Pugach v. Dollinger, 365 U.S. 458 (1961); Wilson v. Schnettler, 365 U.S. 381, 385 (1961); Rea v. United States, 350 U.S. 214, 221 (1956) (Harlan, J., dissenting); Stefanelli v. Minard, 342 U.S. 117, 122 (1951). 
no need for prospective relief because their evidentiary claim could be presented in the state criminal court without repeating their violation or otherwise exposing themselves to additional risk. Moreover, federal interference with evidentiary rulings in a state trial would have split control of the trial between two courts, a result more disruptive than enjoining initiation of the state proceeding.

Douglas was thus not implicated in any of these cases. Yet in three of them, ${ }^{127}$ the Court spoke generally of equitable restraint with respect to criminal prosecutions, cited Douglas, and restated its dictum in sweeping terms. Justice Douglas, on the other hand, in a dissenting opinion to another of these cases, ${ }^{128}$ noted that "[i]njunction against the commencement of state court criminal proceedings has long been the first line of defense for federally secured rights," 129 citing Douglas but apparently only as an unexplained deviation from the general rule. ${ }^{130}$

Four other references to Douglas deserve mention. Bailey $v$. Patterson ${ }^{131}$ involved a challenge to Mississippi laws requiring racial segregation of plane, train, and bus stations. Some three hundred state prosecutions were pending ${ }^{132}$ when three blacks who had not been prosecuted sought a federal injunction on behálf of a large class, including the black defendants in the state prosecutions. A three-judge district court ordered Pullman abstention. The plaintiffs appealed and asked the Supreme Court to stay the prosecutions pending appeal. The Court refused in a one-paragraph per curiam opinion. First it commented that such a stay would be an extraordinary remedy, with citations, introduced by "cf.," to Douglas and Young. Then it said there was a serious standing question since the class representatives had not been prosecuted.

That the Court's cryptic citation to Douglas and Young was not intended to revive the Douglas dictum is clear from its ultimate disposition of the appeal. ${ }^{133}$ The Court concluded that the class rep-

${ }^{127}$ Cleary v. Bolger, 371 U.S. 392, 397 (1963); Wilson v. Schnettler, 365 U.S. 381, 385 (1961); Stefanelli v. Minard, 342 U.S. 117, 122 (1951).

${ }^{128}$ Pugach v. Dollinger, 365 U.S. 458 (1961).

${ }^{129}$ Id. at $462 \mathrm{n} .3$ (Douglas, J., dissenting) (emphasis in original).

${ }^{130}$ Id. See also Larson v. Domestic \& Foreign Commerce Corp., 337 U.S. 682 , 690 (1949) (Vinson, C.J., for the Court) ("injunctions against the threatened enforcement of unconstitutional statutes are familiar examples of" relief not barred by sovereign immunity) (dictum). 131368 U.S. 346 (1961).

${ }^{132}$ Bailey v. Patterson, 199 F. Supp. 595, 612 (S.D. Miss. 1961) (Rives, J., dissenting). For contemporary accounts of this litigation, see B. Marshatl, Federalism aNd Civil Rights 63-84 (1964); Lusky, Racial Discrimination and the Federal Law: A Problem in Nullification, 63 Colum. L. REv. 1163, 1179-80 (1963).

133 369 U.S. 31 (1962). 
resentatives had standing to challenge future enforcement of the segregation statutes and that the state's defense was so frivolous that a single district judge could issue the injunction. The two Bailey opinions make sense in terms of the Young dilemma. With respect to the future events at issue on appeal, the plaintiffs faced the choice of risking penalties or forfeiting rights. But the motion for stay had been directed only to pending prosecutions, which could be defended without repeating the violation and thus increasing the risk of penalties. Bailey was thus consistent with Young and Toomer.

In Stainback v. Mo Hock Ke Lok Po, ${ }^{134}$ the Court relied on Douglas and refused to interfere with a territorial statute restricting the teaching of foreign languages. The Court emphasized that the statute could be enforced only by injunction, that the plaintiffs had "no reason to fear a court of equity,"135 and that the "lack of coercion by fine or imprisonment" was "important" to its decision. ${ }^{136}$ Even so, the plaintiffs faced a dilemma similar to the Young dilemma: they could not provoke an enforcement proceeding without opening schools and could not open schools without spending substantial sums of money that could not be recovered if the statute were upheld. At one point the Court "assume[d]" that the plaintiffs would face irreparable injury, ${ }^{137}$ but that assumption is inconsistent with its insistence that the plaintiffs had nothing to fear and would be "fully protected" in the territorial equity courts. ${ }^{138}$ It held "as a matter of . . . discretion" that no injunction should issue to prevent equity proceedings to enforce an unconstrued territorial statute. ${ }^{139}$ Stainback might plausibly be construed as an actual application of the Douglas dictum. But the distinction of statutes carrying coercive penalties suggests that the Court genuinely viewed Stainback as a special case not presenting a true Young dilemma-that it considered the risk of spending money that might turn out to be wasted qualitatively different from the risk of penalties.

In a third case, St. John v. Wisconsin Employment Relation Board, ${ }^{140}$ the Court squarely applied the narrow holding of Douglas. ${ }^{141}$ The Court struck down the challenged statute in a com-

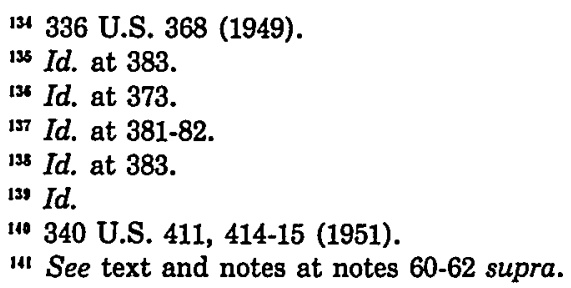


panion case $\mathrm{e}^{142}$ arising on direct appeal from a state enforcement proceeding, and consequently found no need to issue an injunction. Finally, in Fay $v$. Noia ${ }^{143}$ the Court cited Douglas to illustrate the distinction between rights and remedies, a reference consistent with either a broad or narrow reading.

Careful research has not disclosed a single case in the Supreme Court during the twenty-two year period from Douglas to Dombrowski in which the Douglas dictum was unambiguously applied to deny prospective relief in the face of threatened enforcement proceedings. Stainback comes the closest and would be a clear exception but for the emphasis on the equitable nature of the enforcement proceedings. After 1949, the Douglas dictum survived in only three or four bits of dicta, ${ }^{144}$ while holding after holding went the other way.

The lower courts responded to these developments with considerable confusion. Some concluded that Douglas had been modified; ${ }^{145}$ some read it narrowly; $;^{146}$ some simply ignored it; ${ }^{147}$ some gave

${ }^{142}$ Street, Elec. Ry. \& Motor Coach Employees, Div. 998 v. Wisconsin Employment Relations Bd., 340 U.S. 383 (1951).

${ }^{143} 372$ U.S. 391,427 (1963).

14 See cases cited in note 127 supra \& note 260 infra.

145 Dilworth v. Riner, 343 F.2d 226, 231-32 (5th Cir. 1965); United States v. Wood, 295 F.2d 772, 782-84 (5th Cir. 1961), cert. denied, 369 U.S. 850 (1962); Morrison v. Davis, 252 F.2d 102 (5th Cir.), cert. denied, 356 U.S. 968 (1958). See also Dombrowski v. Pfister, 227 F. Supp. 556, 579-83 (E.D. La. 1964) (Wisdom, J., dissenting), rev'd, 380 U.S. 479 (1965); Bailey v. Patterson, 199 F. Supp. 595, 615-16 (S.D. Miss. 1961) (Rives, J., dissenting), vacated, 369 U.S. 31 (1962).

146 Corsican Prods. v. Pitchess, 338 F.2d 441, 443 (9th Cir. 1964); Baines v. City of Danville, 337 F.2d 579, 591-96 (4th Cir. 1964) (en banc), cert. denied, 381 U.S. 939 (1965); Moss v. Hornig, 314 F.2d 89, 91 (2d Cir. 1963); Reid v. City of Norfolk, 179 F. Supp. 768, 771-73 (E.D. Va. 1960); Crown Kosher Super Mkt., Inc. v. Gallagher, 176 F. Supp. 466, 471 (D. Mass 1959), rev'd on the merits, 366 U.S. 617 (1961); International Longshoremen's Union v. Ackerman, 82 F. Supp. 65, 106-12 (D. Hawaii 1949), rev'd, 187 F.2d 860 (9th Cir.), cert. denied, 342 U.S. 859 (1951).

117 Poole v. Barnett, 336 F.2d 267 (5th Cir. 1964); Bailey v. Patterson, 323 F.2d 201, 205 (5th Cir. 1963), cert. denied, 376 U.S. 910 (1964); Anderson v. City of Albany, 321 F.2d 649, 652-53 (5th Cir. 1963); Baines v. City of Danville, 321 F.2d 643 (4th Cir. 1963) (injunction pending appeal), modified, 337 F.2d 579 (1964) (en banc) (final disposition), cert. denied, 381 U.S. 939 (1965); United States v. City of Jackson, 318 F.2d 1, 11, modified on other grounds, 320 F.2d 870 (5th Cir. 1963); Baldwin v. Morgan, 287 F.2d 750 (5th Cir. 1961); City of Montgomery v. Gilmore, 277 F.2d 364 (5th Cir. 1960); Baldwin v. Morgan, 251 F.2d 780, 787 (5th Cir. 1958); Atchison, T. \& S.F. Ry. v. City of Chicago, 240 F.2d 930 (7th Cir. 1957), aff'd, 357 U.S. 77 (1958); Holmes v. City of Atlanta, 223 F.2d 93 (5th Cir. 1955), vacated on other grounds mem., 350 U.S. 879 (1955); Dawson v. Mayor of Baltimore City, 220 F.2d 386 (4th Cir. 1955), aff'd mem., 350 U.S. 877 (1955); Board of Trade v. Illinois Commerce Comm'n, 156 F.2d 33 (7th Cir. 1946), rev'd in part, on the merits, sub nom. Rice v. Santa Fe Elevator Corp., 331 U.S. 218 (1947); Ammex Warehouse Co. v. Department of Alcoholic Beverage Control, 224 F. Supp. 546 (S.D. Cal. 1963), aff'd mem., 378 U.S. 124 (1964); Barthe v. City 
it lip service but decided prospective-relief cases on the merits anyway. ${ }^{148}$ Some concluded that Douglas did not apply to cases involving "vital" or "fundamental human liberties."149 But others considered and rejected the argument that it had been modified; ${ }^{150}$ still others applied it vigorously without acknowledging that anything had happened to cast doubt on it, ${ }^{151}$ or restated its dictum broadly

of New Orleans, 219 F. Supp. 788 (E.D. La. 1963), aff'd, 376 U.S. 189 (1964); Idlewild Bon Voyage Liquor Corp. v. Epstein, 212 F. Supp. 376 (S.D.N.Y. 1962), aff'd, 377 U.S. 324 (1964); Skrupa v. Sanborn,'210 F. Supp. 200 (D. Kan. 1961), rev'd on the merits sub nom. Ferguson v. Skrupa, 372 U.S. 726 (1963); Polar Ice Cream \& Creamery Co. v. Andrews, 208 F. Supp. 899 (N.D. Fla. 1962), rev'd on the merits, 375 U.S. 361 (1964); Hussey v. Campbell, 189 F. Supp. 54 (S.D. Ga. 1960), aff'd, 368 U.S. 297 (1961); Griffin v. Collins, 187 F. Supp. 149 (D. Md. 1960); Braunfeld v. Gibbons, 184 F. Supp. 352 (E.D. Pa. 1959), aff'd sub nom. Braunfeld v. Brown, 366 U.S. 599 (1961); Louisiana ex rel. Gremillion v. NAACP, 181 F. Supp. 37 (E.D. La. 1960), aff'd, 366 U.S. 293 (1961); Two Guys, Inc. v. McGinley, 179 F. Supp. 944 (E.D. Pa. 1959), aff'd, 366 U.S. 582 (1961); Pudlik v. Public Serv. Co., 166 F. Supp. 921 (D. Colo. 1958); Navajo Freight Lines v. Bibb, 159 F. Supp. 385 (S.D. Ill. 1958), aff'd, 359 U.S. 520 (1959); Doud v. Hodge, 146 F. Supp. 887, 890 (N.D. Ill. 1956), aff'd sub nom. Morey v. Doud, 354 U.S. 457 (1957); Browder v. Gayle, 142 F. Supp. 707 (M.D. Ala. 1956), aff'd mem., 352 U.S. 903 (1956); Russo v. Reed, 93 F. Supp. 554, 558 (D. Me. 1950); Mo Hock Ke Lok Po v. Stainback, 74 F. Supp. 852 (D. Hawaii 1947), rev'd, 336 U.S. 368 (1948); Goesaert v. Cleary, 74 F. Supp. 735 (E.D. Mich. 1947), aff'd, 335 U.S. 464 (1948); Toomer v. Witsell, 73 F. Supp. 371,374 (E.D.S.C. 1947), aff'd in relevant part, 334 U.S. 385 (1948); Allen v. Killoran, 56 F. Supp. 173 (D. Del. 1944); Eubanks v. Tucker, 54 F. Supp. 1001, 1003 (S.D. Tex. 1944).

${ }_{118}$ Denton v. City of Carrollton, 235 F.2d 481, 484-87 (5th Cir. 1956); Royal News Co. v. Schultz, 230 F. Supp. 641 (E.D. Mich. 1964), modified on other grounds, 350 F.2d 302 (6th Cir. 1965); Clark v. Thompson, 206 F. Supp. 539 (S.D. Miss. 1962), aff'd, 313 F.2d 637 (5th Cir. 1963); Bailey v. Patterson, 206 F. Supp. 67, 70 (S.D. Miss. 1962), modified on other grounds, 323 F.2d 201 (5th Cir. 1963), cert. denied, 376 U.S. 910 (1964); Bush v. Orleans Parish School Bd., 194 F. Supp. 182, 185 (E.D. La.), aff'd mem. sub nom. Tugwell v. Bush, 367 U.S. 907 (1961); NAACP v. Patty, 159 F. Supp. 503, 521 (E.D. Va. 1958), vacated to permit Pullman abstention sub nom. Harrison v. NAACP, 360 U.S. 167 (1959); Lee Optical v. Williamson, 120 F. Supp. 128, 143-44 n.37 (W.D. Okla. 1954), rev'd on the merits, 348 U.S. 483 (1955); Blass v. Weigel, 85 F. Supp. 775 (D.N.J. 1949). See also Hall v. Hawaiian Pineapple Co., 72 F. Supp. 533, 535 (D. Hawaii 1947).

119 Alesna v. Rice, 74 F. Supp. 865, 870-71 (D. Hawaii 1947), aff'd, 172 F.2d 176 (9th Cir.), cert. denied, 338 U.S. 814 (1949); Stapleton v. Mitchell, 60 F. Supp. 51, 54-55 (D. Kan.), appeal dismissed by stipulation sub nom. McElroy v. Mitchell, 326 U.S. 690 (1945).

150 Reid v. City of Norfolk, 170 F. Supp. 768, 771-73 (E.D. Va. 1960). See also United States v. Wood, 295 F.2d 772, 785-87 (5th Cir. 1961) (Cameron, J., dissenting), cert. denied, 369 U.S. 850 (1962).

151 Outdoor Am. Corp. v. City of Philadelphia, 333 F.2d 963 (3d Cir.), cert. denied, 379 U.S. 903 (1964); Heron v. City of Denver, 317 F.2d 309 (10th Cir. 1963); Fuqua v. United Steelworkers, 253 F.2d 594, 597-99 (6th Cir. 1958); Alesna v. Rice, 172 F.2d 176, 178 (9th Cir.), cert. denied, 338 U.S. 814 (1949); United Steelworkers v. Bagwell, 239 F. Supp. 626, 627-28 (W.D.N.C. 1965), rev'd, 383 F.2d 492 (4th Cir. 1967); Wells v. Hand, 238 F. Supp. 779, 785 (M.D. Ga. 1965), aff'd mem., 382 U.S. 39 (1965); Cameron v. Johnson, 244 F. Supp. 846 (S.D. Miss. 1964), vacated, 381 U.S. 741 (1965); Dombrowski v. Pfister, 227 F. Supp. 556 (E.D. La. 1964), rev'd, 380 U.S. 479 (1965); Chase v. McCain, 220 F. Supp. 407, 409 (W.D. Va. 1963), aff'd sub nom. Baines v. City of Danville, 337 F.2d 574 (4th Cir. 1964) (en banc), cert. denied, 381 U.S. 939 (1965); Zellner v. Lingo, 218 F. Supp. 513, 516 (M.D. Ala. 1963), aff'd mem., 334 F.2d 620 (5th Cir. 1964); Grove Press, Inc. v. Calissi, 208 F. Supp. 580, 583 (D.N.J. 1962); 
in situations where it did not apply. ${ }^{152}$

Simply counting these cases may underestimate the frequency with which prospective relief was granted, for the decisions that ignore Douglas cannot be found in any systematic way. But it is clear that lower federal courts decided claims for prospective relief on the merits considerably more often than not ${ }^{153}$ and that the Supreme Court routinely entertained such claims whenever they otherwise deserved plenary review. Thus, it is simply not true that the "doors of the federal equity court" were "long shut by Douglas."154 Some courts were closed, but many others were not. What should have been important in the long run was that the doors to the Supreme Court stood open. These are the forgotten precedents;

Arrow Lakes Dairy, Inc. v. Gill, 200 F. Supp. 729, 732 (D. Conn. 1961); Henderson v. Trailway Bus Co., 194 F. Supp. 423, 427-28 (E.D. Va. 1961) (alternative holding), aff'd mem. sub nom. Robinson v. Hunter, 374 U.S. 488 (1963); Toth v. Silbert, 184 F. Supp. 163, 167 (N.D. Ohio 1960); Times Film Corp. v. City of Chicago, 180 F. Supp. 843, 845 (N.D. Ill. 1959) (alternative holding), aff'd on the merits, 365 U.S. 43 (1961); Magtab Publishing Corp. v. Howard, 169 F. Supp. 65, 70 (W.D. La. 1959); Kingsley Int'l Pictures Corp. v. City of Providence, 166 F. Supp. 456, 459 (D.R.I. 1958); Dawley v. City of Norfolk, 159 F. Supp. 642, 646 (E.D. Va.), aff'd, 260 F.2d 647 (4th Cir. 1958), cert. denied, 359 U.S. 935 (1959); Browder v. City of Montgomery, 146 F. Supp. 127, 131 (M.D. Ala. 1956); Denton v. City of Carrollton, 132 F. Supp. 302, 303.04 (N.D. Ga. 1955), rev'd, 235 F.2d 481 (5th Cir. 1956); ILGWU v. Seamprufe, 121 F. Supp. 165, 167, further proceedings, 130 F. Supp. 737, 738-39 (E.D. Okla. 1955); Linehan v. Waterfront Comm'n, 116 F. Supp. 401, 404-05 (S.D.N.Y. 1953); Algonquin Gas Transmission Co. v. Township of Bernards, 112 F. Supp. 86, 91 (D.N.J. 1953); Atchison, T. \& S.F. Ry. v. Ross, 88 F. Supp. 451, 456 (W.D. Mo. 1950); Bowers v. Calkins, 84 F. Supp. 272, 278-79 (D.N.H. 1949); Priceman v. Dewey, 81 F. Supp. 557, 559 (E.D.N.Y. 1949); Society of Good Neighbors v. Groat, 77 F. Supp. 695, 697 (E.D. Mich. 1948); Lammon v. City of San Francisco, 64 F. Supp. 154, 155 (N.D. Cal. 1946).

152 Potter v. Missouri, 325 F.2d 525, 526 (8th Cir. 1963); Wojcik v. Palmer, 318 F.2d 171, 173 (7th Cir.), cert. denied, 375 U.S. 930 (1963); Empire Pictures Distrib. Co. v. City of Fort Worth, 273 F.2d 529, 538-40 (5th Cir. 1960); Ackerman v International Longshoremen's Union, 187 F.2d 860 (9th Cir.), cert. denied, 342 U.S. 859 (1951); Bomar v. Keyes, 162 F.2d 136, 139 (2d Cir.), cert. denied, 332 U.S. 825 (1947); Bowles v. Hayes, 155 F.2d 351, 353-55 (3d Cir. 1946); New York v. Berger, 239 F. Supp. 219, 226 (S.D.N.Y. 1965); Chafee v. Johnson, 229 F. Supp. 445, 447 (S.D. Miss. 1964), aff'd, 352 F.2d 514 (5th Cir. 1965), cert. denied, 384 U.S. 956 (1966); Bailey v. Patterson, 199 F. Supp. 595, 602 (S.D. Miss. 1962), rev'd, 369 U.S. 31 (1963); In re Wyckoff, 196 F. Supp. 515, 519-20 (S.D. Miss. 1961); Jacobs v. Sullivan, 193 F. Supp. 765, 766 (D. Mass. 1961); Pugach v. Klein, 193 F. Supp. 630, 637 (S.D.N.Y. 1961); Voci v. Farkas, 144 F. Supp. 103, 105-06 (E.D. Pa. 1956); DeVasto v. Hoyt, 101 F. Supp. 908, 910 (S.D.N.Y. 1951); Teeval, Inc. v. City of New York, 92 F. Supp. 827, 832 (S.D.N.Y. 1949); Cooper v. Hutchinson, 88 F. Supp. 774, 782 (D.N.J. 1950), rev'd, 184 F.2d 119 (3d Cir. 1950); East Coast Lumber Terminal, Inc. v. Town of Babylon, 81 F. Supp. 701, 705 (E.D.N.Y. 1949), aff'd, 174 F.2d 106 (2d Cir. 1949); Sellers v. Johnson, 69 F. Supp. 778, 783 (S.D. Iowa 1946), rev'd, 163 F.2d 877 (8th Cir. 1947), cert. denied, 332 U.S. 851 (1948); United States v. Renken, 55 F. Supp. 1, 9 (W.D.S.C. 1944), aff'd sub nom. Old Monastery Co. v. United States, 147 F.2d 905 (4th Cir.), cert. denied, 326 U.S. 734 (1945).

${ }^{153}$ Compare notes 145-149 supra with notes 150-151 supra.

134 Fiss, supra note 17, at 1163. 
since Dombrowski, they have disappeared from the cases and the literature.

\section{The Doctrinal Effects of Dombrowski}

\section{A. Short Run Effects-Dombrowski to Steffel}

Dombrowski looks quite different against the background of the forgotten precedents. Prospective relief had been generally available without regard to the plaintiff's substantive constitutional theory. After Dombrowski, such relief was available only in exceptional cases-perhaps only in first amendment overbreadth cases. The Court resurrected the Douglas dictum, which had not been cited in a case to which it applied since 1949, adopted it as the framework for analysis, and said that it had modified the rule of Ex parte Young. ${ }^{155}$ Young's scores of progeny were ignored and effectively buried. Dombrowski made prospective relief presumptively unavailable and shifted the focus of debate from applications of the general rule of Young to exceptions to the general rule of Douglas.

This was not simply a semantic shift, after which the Young dilemma continued as a generally recognized exception to the Douglas dictum. ${ }^{158}$ Dombrowski abandoned the common-sense principle that a citizen should not have to risk imprisonment to learn what his rights are. This principle had given rise to Young, the Declaratory Judgment Act, Toomer $v$. Witsell, and the Court's almost unbroken practice from 1908 to 1965 . Resurrection of the Douglas dictum indicated abandonment of the principle; Dombrowski's explanation of why overbreadth claims were exceptional made it unmistakably clear:

A criminal prosecution under a statute regulating expression usually involves imponderables and contingencies that themselves may inhibit the full exercise of First Amendment freedoms. When the statutes also have an overbroad sweep, as is here alleged, the hazard of loss or substantial impairment of those precious rights may be critical. For in such cases, the statutes lend themselves too readily to denial of those rights. The assumption that defense of a criminal prosecution will generally assure ample vindication of constitutional rights is unfounded in such cases. For "[t]he threat of sanctions may deter . . . almost as potently as the actual application of sanc- 
tions. . . ."Because of the sensitive nature of constitutionally protected expression, we have not required that all of those subject to overbroad regulations risk prosecution to test their rights. For free expression-of transcendent value to all society, and not merely to those exercising their rights-might be the loser..$^{157}$

This passage, especially in light of the Douglas dictum, strongly implies that citizens subject to other kinds of regulations are required to risk prosecution to test their rights. Moreover, the Court's assumption that "defense of a criminal prosecution will generally assure ample vindication of constitutional rights"158 cannot be read as limited to situations in which a plaintiff has already run the risk of penalties and contemplates no further violations, for the Court found the criminal remedy inadequate in the overbreadth context precisely because the risk of penalties chills speech. The implication is that a criminal defense remains adequate in other contexts despite the risk of penalties. The effect of the Court's ringing endorsement of the Douglas dictum is thus to deny the significance of the Young dilemma except in overbreadth cases.

This understanding of Dombrowski casts new light on the subsequent litigation in which the Court hammered out the complex rules that now govern federal prospective relief. Justice Brennan's opinion in Dombrowski has been viewed as a rallying point for Justices seeking to expand the availability of prospective relief and an obstacle to those seeking to restrict it. ${ }^{159}$ Dombrowski has in fact played exactly the opposite role. In the course of deciding Younger, Justice Black easily disposed of Dombrowski's overbreadth exception, ${ }^{160}$ and there is no evidence in subsequent opinions that Dombrowksi has had any other restraining influence on the Burger Court. But Dombrowski's resurrection of Douglas and its burial of the forgotten precedents have continued to haunt supporters of prospective relief, forcing them to make important concessions and to rely on artificial distinctions to preserve the availability of any prospective relief at all.

These effects of Dombrowski can be seen in two pre-Younger cases. In each, Justice Brennan's opinion for the Court repeated the Douglas dictum, cited Dombrowski to show that Douglas was still good law, and kept exceptions narrowly confined. The first,

\footnotetext{
${ }^{157} 380$ U.S. at 486 (emphasis added) (citations omitted).

158 Id.

159 See Fiss, supra note 17.

1 to 401 U.S. at 50-51.
} 
Zwickler $v$. Koota, ${ }^{181}$ presented an overbreadth claim. Yet the district court held the claim to be outside the overbreadth exception, because the plaintiff's rights could be vindicated in a single state proceeding. ${ }^{162}$ This was clearly erroneous not only because it ignored the overbreadth exception's emphasis on the rights of other potential speakers, ${ }^{163}$ but because the plaintiff had already litigated one state proceeding without resolving his constitutional claim. ${ }^{184}$ The Supreme Court reversed on an arguably narrower ground, remanding for consideration of whether the plaintiff was entitled to declaratory relief, and noting that declaratory judgments were not necessarily subject to the same restrictions as injunctions. Thus, looking forward, Zwickler foreshadows the new importance to be attached to the distinction between injunctive and declaratory relief. ${ }^{165}$ Looking backward, however, Zwickler is a measure of the immediate impact of Dombrowski: under the forgotten precedents an injunction would have issued routinely.

The second case, Cameron $v$. Johnson, ${ }^{166}$ came before the Court twice. Cameron $I^{187}$ resulted in a remand for consideration in light of Dombrowski and was read as signaling a broad interpretation of Dombrowski's exceptions. ${ }^{188}$ Cameron $I I^{169}$ produced an opinion that dashed such hopes. The case presented a compelling claim for prospective relief: the plaintiffs had abandoned a voting-rights picket line because of arrests under the challenged statute. Prosecutions were still pending, but the Court attached no significance to that fact. Instead, it rejected an overbreadth challenge on the merits and then held that Douglas barred consideration of a claim that the statute was unconstitutional as applied. Such a claim, it found, fit neither within the Dombrowski overbreadth exception nor within a newly enunciated bad-faith-harassment exception. Bad-faith harassment was unaccountably taken from its place in Dombrowski's discussion of Pullman abstention ${ }^{170}$ and treated as an additional and

I1I 389 U.S. 241 (1967).

162 Zwickler v. Koota, 261 F. Supp. 985, 992-93 (E.D.N.Y. 1966), rev'd on other grounds, 389 U.S. 241 (1967).

"s Dombrowski v. Pfister, 380 U.S. 479, 486 (1965).

w1 261 F. Supp. at 987.

105 See text and notes at notes 192-199 infra.

166244 F. Supp. 846 (S.D. Miss. 1964), vacated, 381 U.S. 741 (1965), further proceedings,

262 F. Supp. 873 (S.D. Miss. 1966), aff'd, 390 U.S. 611 (1968).

167381 U.S. 741 (1965).

$16 \times$ See Bailey, supra note 27, at 107-09.

163 390 U.S. 611 (1968).

${ }^{170}$ See text and note at note 14 supra. 
independent exception to the Douglas dictum. The Court construed the exception so narrowly, however, as to render it almost meaningless, and denied relief because bad-faith harassment had not been proved.

Since this bad-faith-harassment exception later became the vehicle for disposing of the overbreadth exception, Cameron II initiated the process that would ultimately eliminate Dombrowski's sole concession to the need for prospective relief. At the same time, Dombrowski's shift of emphasis from Young to Douglas was clearly felt. Although the Anti-Injunction Act might have barred injunctions against the pending prosecutions for past violations, ${ }^{171}$ the preDombrowski Court would likely have deemed those prosecutions irrelevant to the request for injunctions against any further prosecutions. ${ }^{172}$ Moreover, even if the pre-Dombrowski Court would have denied relief, it certainly would not have done so for lack of irreparable injury, for the Young dilemma was properly invoked. Cameron $I I$ is thus a direct result of Dombrowski's having denied the significance of the Young dilemma.

Dombrowski and Cameron II paved the way for Younger $v$. Harris, ${ }^{173}$ which together with its companion cases ${ }^{174}$ made prospective relief generally unavailable when a state prosecution is pending. Writing for the Court in Younger, Justice Black began his analysis by repeating the Douglas dictum and reviewing the aberrational line of cases cited in Dombrowski. Without further discussion, he flatly asserted that " $[t]$ his is where the law stood when the Court decided Dombrowski. . . ,"175 an assertion that was simply untrue. Since the general rule in Dombrowski had been announced with respect to prosecutions that the Court explicitly found were only threatened, ${ }^{176}$ application of that rule to cases involving pending prosecutions followed a fortiori. In addition, Justice Black completed the task of rejecting Dombrowski's only exception. Arguing that the overbreadth exception was dictum, which it was not, ${ }^{177}$ and logically

171 But see Mitchum v. Foster, 407 U.S. 225 (1972); Rice v. Santa Fe Elevator Corp., 331 U.S. 218 (1947) (enjoining pending administrative enforcement proceeding initiated by private defendants before defendant state commission).

172 See cases cited in note 201 infra.

173401 U.S. 37 (1971).

174 Byrne v. Karalexis, 401 U.S. 216 (1971); Dyson v. Stein, 401 U.S. 200 (1971); Perez v. Ledesma, 401 U.S. 82 (1971); Boyle v. Landry, 401 U.S. 77 (1971);Samuels v. Mackell, 401 U.S. 66 (1971).

175401 U.S. at 47.

176 See text and notes at notes 16-18 supra.

177 See Fiss, supra note 17, at 1112. See also Justice Black's inconsistent view in Cameron v. Johnson, 381 U.S. 741, 748-49, 752 (1965) (dissenting) (both overbreadth and harassment required to show irreparable injury under Dombrowski). 
flawed, which it was, ${ }^{178}$ he incorrectly attributed Dombrowski's result to bad-faith harassment, a category Cameron II had already indicated was empty.

Justice Brennan's opinion in Dombrowski is obviously not responsible for Younger's rejection of the overbreadth exception. And Justice Black's apparent zeal for banning prospective relief accounts for the harshness of Younger's rhetoric. But Younger's account of the precedents and its rule that prospective relief is generally unavailable were straight out of Dombrowski. At the very least Justice Black should have had to deal with the contrary precedents and to confront the Young dilemma before denouncing prospective relief. By reinstating the Douglas dictum as the general rule and burying the supervening precedents, Dombrowski permitted him instead to portray Younger as the logical outgrowth of decades of precedent.

Younger purported to express no view about requests for prospective relief filed before commencement of any state prosecution, ${ }^{179}$ and two Justices emphasized that point in a concurrence. ${ }^{180}$ But two aspects of the Younger opinion undermined these disclaimers. First, the Court chose not to argue, as it might have, that the overbreadth exception was limited to cases in which the Court found no prosecution pending. Rather, as in Cameron II, the Court implicitly assumed that the applicability of Dombrowski's exceptions did not depend on whether a prosecution was pending. Second, and more importantly, the Court said that the Douglas line of cases "made clear" that a suit for prospective relief, "even with respect to state criminal proceedings not yet formally instituted, could be proper only under very special circumstances." 181

The Fifth Circuit took these implications seriously in Becker $v$. Thompson, ${ }^{182}$ in which the court denied a plaintiff prospective relief even though he squarely faced the Young dilemma and no prosecution was pending. The majority read Younger as making it "clear beyond peradventure" that even an unprosecuted plaintiff must be denied relief unless he could show bad-faith harassment. ${ }^{183}$ As Judge Tuttle's concurring opinion indicates, however, Younger's role was really quite limited. Disagreeing with the majority's reading of that

\footnotetext{
${ }^{178} 401$ U.S. at 50-52; see Fiss, supra note 17, at 1111-14.

17401 U.S. at 41.

${ }^{1 \times 0}$ Id. at 55 (Stewart, J., joined by Harlan, J., concurring).

${ }^{1 \times 1}$ Id. at 45 (opinion of the Court) (emphasis added).

i×2 459 F.2d 919 (5th Cir. 1972), rev'd sub nom. Steffel v. Thompson, 415 U.S. 452 (1974).

${ }^{185}$ Id. at 922; see The Supreme Court, 1970 Term, supra note 27, at 304-05. Contra, Wulp v. Corcoran, 454 F.2d 826, 830-32 (1st Cir. 1972).
} 
case, Judge Tuttle nevertheless concurred in the result on the gound that Dombrowski itself required dismissal because the plaintiffs had shown neither overbreadth nor bad-faith harassment. ${ }^{184}$ This direct invocation of Dombrowski is hardly surprising: the majority itself relied on those parts of Younger resting squarely on the earlier case. Indeed, Dombrowski was actually the more direct precedent, for like Dombrowski and unlike Younger, Becker was a case in which no prosecution was pending. ${ }^{185}$ Younger's only independent contribution to the result in Becker was abolition of the overbreadth exception, which made it unnecessary for the majority to reject the overbreadth challenge on the merits.

Had the Supreme Court upheld the Fifth Circuit's interpretation of Dombrowski and Younger, Ex parte Young would have been effectively overruled. But the Supreme Court reversed Becker in Steffel $v$. Thompson. ${ }^{186}$ Steffel once again made prospective relief generally available when no enforcement proceeding is pending. This result occurred in spite of Dombrowski, however, not because of it. Indeed, as Judge Tuttle's concurrence below indicated, Steffel was squarely inconsistent with the rules announced in Dombrowski. Thus, the defendants relied on Dombrowski for affirmance. ${ }^{187}$ The plaintiff relied on Dombrowski only to demonstrate that Younger announced no new law, ${ }^{188}$ and did not even cite Dombrowski in the section of his brief arguing that he was entitled to a declaratory judgment. ${ }^{189}$ Most importantly, Steffel's rationale was not overbreadth, but the classic Young dilemma, which the Court characterized as the "Scylla of intentionally flouting state law and the Charybdis of foregoing what he believed to be constitutionally protected activity."190 Based on the venerable principle that individuals should not have to risk prosecution to test their rights, Steffel is the legitimate descendant of Young, the Declaratory Judgment Act, and the scores of cases Dombrowski buried. Ultimately, the need for relief from the Young dilemma is so compelling that when the issue was squarely presented, as it was in Steffel, the Court found it necessary to return to traditional practice even without the aid of the forgotten precedents.

is 459 F.2d at 924.

${ }_{185}$ See text and notes at notes 16-18 supra.

$1 s 8415$ U.S. 452 (1974). For decisions foreshadowing Steffel, see Roe v. Wade, 410 U.S. 113, 123-24 (1973); Lake Carriers' Ass'n v. MacMullan, 406 U.S. 498, 509-10 (1972).

${ }^{187}$ Brief for Respondents Hudgens and Reynolds at 5-7, Steffel v. Thompson, 415 U.S. 452 (1974).

iss Brief for Petitioners at 9, 11-25, id.

180 Id. at 26-34.

190415 U.S. at 462 (1974), quoted in Wooley v. Maynard, 430 U.S. 705, 710 (1977). 


\section{B. Continuing Effects-The Younger Doctrine}

Although Steffel and its progeny have again made prospective relief routine when no enforcement proceeding is pending, ${ }^{191}$ the restoration of past practice is not complete. There are at least three important differences between the present rules and the preDombrowski practice, each of them to a greater or lesser extent the result of Dombrowski. The first is that declaratory judgments have generally been substituted for injunctions. ${ }^{192}$ Dombrowski and the portion of Younger derived from it have remained as obstacles to any holding that the Young dilemma satisfies the irreparable injury requirement. Steffel avoided the issue by granting a declaratory judgment, emphasizing that equity's irreparable injury requirement does not apply to this statutory remedy and reserving the question whether injunctions against enforcement would ever be available. ${ }^{193}$

An adequately enforced declaratory judgment will protect a citizen in the Young dilemma as effectively as an injunction. ${ }^{194}$ Not surprisingly therefore, nothing has yet turned on the distinction, and its importance may be fading: the post-Steffel Court has in fact affirmed one injunction in arguably special circumstances, ${ }^{195}$ and two others without comment in quite ordinary circumstances. ${ }^{196} \mathrm{But}$ the Court has not yet squarely rejected Justice Rehnquist's efforts to reduce declaratory judgments to advisory opinions. ${ }^{197}$ Until the efficacy of declaratory judgments is settled, or the distinction erodes and injunctions become generally available again, Dombrowski's resurrection of Douglas will cast doubt on the full availability of

11 See, e.g., Bellotti v. Baird, 99 S. Ct. 3035 (1979); Mackey v. Montrym, 99 S. Ct. 2612 (1979); Babbitt v. UFW, 99 S. Ct. 2301 (1979); Colautti v. Franklin, 99 S. Ct. 675, 679 n.3 (1979); Ray v. Atlentic Richfield Co., 435 U.S. 151 (1978); Hunt v. Washington State Apple Advertising Comm'n, 432 U.S. 333 (1977); Carey v. Population Servs. Int'l, 431 U.S. 678 (1977); Douglas v. Seacoast Prods., Inc., 431 U.S. 265 (1977); Dixon v. Love, 431 U.S. 105 (1977); Linmark Assocs., Inc. v. Township of Willingboro, 431 U.S. 85 (1977); Planned Parenthood v. Danforth, 428 U.S. 52, 62 (1976).

112 See Steffel v. Thompson, 415 U.S. 452, 463 n.12, 466-73 (1974). But see Bellotti v. Baird, 99 S. Ct. 3035,3052 (1979); Ray v. Atlantic Richfield Co., 435 U.S. 151, 156-57, 180 (1978); Wooley v. Maynard, 430 U.S. 705, $711-12$ (1977); Fiss, supra note 17, at 1144-48; Developments in the Law-Section 1983 and Federalism, 90 HARv. L. Rev. 1133, 1290-91 (1977).

in 415 U.S. at 463 n.12, 466-73.

1" See Laycock, supra note 5, at 216-18.

195 Wooley v. Maynard, 430 U.S. 705, 711-12 (1977).

13 Bellotti v. Baird, 99 S. Ct. 3035, 3052 (1979); Ray v. Atlantic Richfield Co., 435 U.S. 151, 156-57, 180 (1978). See also Zablocki v. Redhail, 434 U.S. 374 (1978) (injunction against denying marriage license; no explanation why declaratory judgment is insufficient).

in Steffel v. Thompson, 415 U.S. 452, 478-84 (1974) (Rehnquist, J., concurring). 
prospective relief even when no enforcement proceeding is pending. The doubt is not serious, but the Court's official stance is that the effect of declaratory judgments ${ }^{188}$ and the availability of injunctions $^{109}$ are both open issues.

If these issues are ever faced, those members of the Court opposed to making prospective relief generally available will be able to rely squarely on the Dombrowski-Younger account of the precedents. Dombrowski and Younger say that fear of prosecution does not justify an injunction except in special circumstances. Logically, then, fear of prosecution should not justify any relief equivalent to an injunction. Those committed to making prospective relief available could insist on maintaining the purely formal distinction between injunctions and declaratory judgments, or they could review all the precedents and acknowledge frankly that the DombrowskiYounger account is historically inaccurate and doctrinally unsound. Alternatively, the Court may be able to avoid these issues indefinitely, or resolve them by accumulating practice without explanation. But for Dombrowski they would not be open at all.

The second and most important difference between present and pre-Dombrowski practice is that prospective relief with respect to contemplated future violations is generally unavailable if an enforcement proceeding is pending with respect to an alleged past violation. ${ }^{200}$ The pre-Dombrowski Court had not squarely faced this issue, but in practice, pending proceedings had not precluded prospective relief against prosecutions for future violations. ${ }^{201}$ The AntiInjunction Act was no bar: even before the Supreme Court found

${ }^{198}$ Id. at $470-71$ (opinion of the Court).

${ }^{199}$ Doran v. Salem Inn, Inc., 422 U.S. 922, 930 (1975); Steffel v. Thompson, 415 U.S. 452, 463 n.12 (1974); Younger v. Harris, 401 U.S. 37, 41 (1971).

200 Laycock, supra note 5, at 196.

${ }^{201}$ See AFL v. Watson, 327 U.S. 582, 588 (1946) (no distinction drawn between prosecuted and unprosecuted plaintiffs); Cline v. Frink Dairy Co., 274 U.S. 434, 452-53, 466 (1927) (pending prosecutions not enjoined; future prosecutions against same parties enjoined); Hall v. Geiger-Jones Co., 242 U.S. 539, 542-44 (1917) (reversing on merits order parallel to that in Cline); Caldwell v. Sioux Falls Stock Yards Co., 242 U.S. 559, 563 (1917) (same); Davis \& Farnum Mfg. Co. v. City of Los Angeles, 189 U.S. 207, 218 (1903) (pending prosecutions irrelevant) (dictum); cf. Bailey v. Patterson, 369 U.S. 31, 32-33 (1962) ("Appellants lack standing to enjoin criminal prosecutions under . . . breach-of-peace statutes, since they have not been prosecuted or threatened with prosecution under them.") (emphasis added); Two Guys, Inc. v. McGinley, 366 U.S. 582, 585-89 (1961) (injunction against threatened prosecutions denied on merits despite pending prosecutions under predecessor statute); Rice v. Santa Fe Elevator Corp., 331 U.S. 218 (1947) (enjoining pending administrative enforcement proceeding initiated by private defendant before defendant state commission); Douglas v. City of Jeanette, 319 U.S. 157, 164 (1943) (no distinction drawn between prosecuted and unprosecuted plaintiffs but relief denied to all). But see Ex parte Young, 209 U.S. 123, 162 (1908) (dictum). 
that the 1871 Civil Rights Act was an expressly authorized exception to the Anti-Injunction Act, ${ }^{202}$ the latter statute did not forbid relief directed to threatened additional proceedings merely because some other proceeding was already pending.

Nor does the irreparable injury rule preclude such relief, for as I have argued extensively elsewhere, ${ }^{203}$ pending criminal prosecutions often do not offer an adequate remedy. Criminal courts lack two great powers of equity courts that are essential to eliminating the Young dilemma: the power to grant prospective relief and the power to grant interlocutory relief. Thus, the mere pendency of an enforcement proceeding does not extricate the state defendant from the Young dilemma if he is contemplating additional violations before a final judgment can be had. ${ }^{204}$ Even a judgment in an enforcement proceeding is not always an adequate remedy, for its prospective effect may be unclear. ${ }^{205}$ These serious defects belie the Court's assumption that defense of a state criminal proceeding is an adequate remedy. But every Justice has indulged in that assumption and the point has gone by default.

Professor Fiss's speculative but largely convincing analysis of the post-Dombrowski cases suggests an explanation of how such a default could have happened. Fiss has suggested that Justice Brennan's opinions in Younger $v$. Harris and Perez $v$. Ledesma, ${ }^{206}$ conceding that prospective relief should be generally unavailable once a prosecution was commenced, were part of a deeply laid strategy to save declaratory judgments where no prosecution was pending. This strategy successfully culminated in Steffel. ${ }^{207}$ But it is now clear that Justice Brennan was struggling to regain part of what he had given away in Dombrowski, and that without Dombrowski the key concession would have been unnecessary. Since the general argument for prospective relief would have been solidly based on the forgotten precedents, leaving prospective relief in the preenforcement situation relatively secure, Justice Brennan and his allies would have been free to dispute the significance of pending prosecutions. Had they taken this opportunity, some of the remedial

${ }^{202}$ Mitchum v. Foster, 407 U.S. 225 (1972).

${ }^{203}$ Laycock, supra note 5, at 196-222.

2as Id. at 202-14.

${ }^{205}$ Id. at 214-22. See, e.g., Zwickler v. Koota, 261 F. Supp. 985, 987 (E.D.N.Y. 1966), rev'd on other grounds, 389 U.S. 241 (1967) (state defendant litigated criminal trial and two appeals without resolving constitutional question because he was acquitted on facts of particular case).

204 401 U.S. 82, 93-136 (dissenting in part).

202 Fiss, supra note 17, at 1121-29. 
inadequacies of the criminal defense might have become important exceptions to the Younger doctrine. But even this formulation reverses the true relationship of the competing principles. If the Court had followed the pre-Dombrowski precedents authorizing injunctions against future enforcement despite the pendency of an earlier prosecution, Younger's refusal to enjoin the pending prosecution would have been merely an exception to the general practice of granting prospective relief.

The third difference between present and pre-Dombrowski practice is that the defendant state officials can now abort a federal suit for prospective relief by filing a retaliatory state enforcement proceeding. ${ }^{208}$ This "reverse removal power" sometimes gives the choice of forum to state officials, even though Congress plainly intended to give that choice to the citizen alleging violation of his federal rights..$^{209}$ The citizen can now be certain of a federal forum only if he abstains from exercising his claimed federal rights until "proceedings of substance on the merits have taken place in federal court." 210 Thus, the Young dilemma is aggravated by adding the risk of adjudication in a state forum ${ }^{211}$ to the risk of penalties.

The reverse removal power derives from the prohibition on relief when an enforcement proceeding is pending. If pending state proceedings did not bar prospective relief, retaliatory proceedings would be irrelevant and the reverse removal power impossible. At most the Court would decline to enjoin the retaliatory proceeding. If contemplated future violations still presented the plaintiff with the Young dilemma, the Court would not assume that the retaliatory proceeding provided an adequate remedy and would not dismiss the federal case. Thus, to the extent Dombrowski led to the present emphasis on pending prosecutions, it also led to the reverse removal power.

In addition, the false image of Younger's precedential base, resulting from Dombrowski, may have independently contributed to the reverse removal power. The case creating that power was decided by a majority of five who thought any other rule would "trivialize" Younger; ${ }^{212}$ the dissenters charged the Court with tri-

${ }^{20 x}$ Doran v. Salem Inn, Inc., 422 U.S. 922, 929 (1975); Hicks v. Miranda, 422 U.S. 332, 349-50 (1975) (alternative holding).

${ }^{209}$ Fiss, supra note 17, at 1134-36.

${ }^{210}$ Hicks v. Miranda, 422 U.S. 332, 349 (1975) (alternative holding). See also Doran v.

Salem Inn, Inc., 422 U.S. 922,929 (1975) ("no contested matter had been decided").

21' See Laycock, supra note 5, at 232-34.

212 Hicks v. Miranda, 422 U.S. 332, 350 (1975) (alternative holding). 
vializing Steffel. ${ }^{213} \mathrm{~A}$ distorted view of the comparative strength of these two precedents may have affected at least one Justice's vote on how to draw the line between them.

Dombrowski's lingering effects may not be limited to these three principal areas. For example, the Burger Court has dramatically restricted the availability of injunctions against unconstitutional administration of state programs that do not require judicial enforcement, ${ }^{214}$ at least when criminal justice agencies are involved. ${ }^{215}$ These restrictions have drawn heavily on the rhetoric of "Our Federalism" in Younger, ${ }^{218}$ and that rhetoric would have been far less sweeping had Dombrowski not obliterated the inconsistent precedents. But Dombrowski's contribution to such collateral developments is far less direct than its impact on the availability of prospective relief in the face of the Young dilemma.

Of course it is possible that all of these developments were political rather than legal events. The Court may have been so determined to restrict federal judicial power that no combination of precedents would have stopped it. ${ }^{217}$ But this possibility merely suggests that if Dombrowski had not existed, it would have been necessary to invent it: the Younger doctrine could not have developed as it did without elimination of the forgotten precedents. Dombrowski accomplished that task with remarkable thoroughness; it was the beginning of the Younger era.

\section{Speculations on the Causes of Dombrowski}

The leading explanation for Dombrowksi's treatment of the irreparable injury requirement has been supplied by Professor Fiss. Fiss has suggested that Justice Brennan was committed to prospective relief and did not believe in the Douglas dictum, but that he acknowledged it in order to hold a majority for his result.218 In this view Justice Brennan hoped to erode Douglas from within, perhaps by creating more exceptions, or perhaps by generalizing upon his recognition that, in the overbreadth context, the risk of penalties could deter constitutionally protected conduct. This explanation would be persuasive if the Douglas dictum had been good law in

${ }^{213}$ Id. at 353 (Stewart, J., dissenting).

214 See text and notes at notes 92-94 supra.

215 Rizzo v. Goode, 423 U.S. 362 (1976); O'Shea v. Littleton, 414 U.S. 488 (1974). See generally Fiss, supra note 17, at 1148-60.

216423 U.S. at $379-80 ; 414$ U.S. at $499-502$.

${ }_{217}$ But see Soifer \& MacGill, supra note 47, at 1167 (suggesting that Justice Black could not admit that Younger was a policy decision).

${ }^{213}$ Fiss, supra note 17, at 1107-08, 1160-64. 
1965. But since the Court had worked out from under Douglas years before and since it would have made no sense for Justice Brennan to resurrect deliberately a rule he hoped to destroy, this explanation is no longer sufficient.

There are three possible theories consistent with the existence of the forgotten precedents. One theory is that the Court-or certain key Justices-determined as a matter of policy to limit the availability of prospective relief, even at the cost of distorting precedent. A second is that the Court overlooked the forgotten precedents and mistakenly thought Douglas to be good law. Finally, a third possibility - a variation of the second-is that the Court knew about the forgotten precedents but mistakenly thought them distinguishable for some reason that was never stated and that has now been forgotten.

The opinion itself is consistent with either of the first two theories. It reads as though the Court were unaware of any case after Douglas, but the Court could have deliberately created that impression. Citation of favorable but obsolete precedent is an obvious technique for changing existing law while giving lip service to precedent. ${ }^{219}$ This technique might have been especially appealing in Dombrowski, since the intervening precedents were not very visi$b^{2} e^{220}$ and the judgment for the plaintiffs tended to distract attention from the doctrinal shift in favor of defendants.

Yet the policy theory must explain why a Court that had been routinely granting prospective relief suddenly changed direction. The facts of the case did not compel such a shift. If the Court had merely been troubled by something about the specific facts of Dombrowski, such as the arguable pendency of the state prosecutions, ${ }^{221}$ it could have created a narrow rule for such cases without resurrecting the Douglas dictum in general terms. Nor was Dombrowski foreshadowed; the Court's immediate pre-Dombrowski opinions do not suggest increasing reluctance to grant prospective relief. To the contrary, prospective relief had been granted with increasing frequency in the early sixties. ${ }^{222}$

Conceivably, this expanded use of prospective relief triggered a reaction. It has been suggested ${ }^{223}$ that the federalism decisions of

${ }^{219}$ See Landes \& Posner, Legal Precedent: A Theoretical and Empirical Analysis, 19

J.L. \& ECON. 249, 274 (1976).

200 See text and notes at notes 250-255 infra.

221 See text and notes at notes 16-18 supra.

222 See cases cited in notes 98-101 supra.

${ }^{223}$ See, e.g., City of Lafayette v. Louisiana Power \& Light Co., 435 U.S. 389, 420-21 (1978)

(Burger, C.J., concurring); Verkuil, State Action, Due Process and Antitrust: Reflections on 
the early forties ${ }^{224}$ were a reaction to economic substantive due process, a doctrine later regarded ${ }^{225}$ as an abuse of judicial power. There could plausibly have been a similar reaction in the sixties when the civil rights movement and the Court's increasing activism focused attention on federalism issues in a way that occasional injunctions against isolated statutes had not. ${ }^{228}$

It is easy to imagine some Justices consciously desiring to abandon the then existing practice. But this explanation is ultimately insufficient to save the policy theory because it is simply impossible to identify any essential members of the Dombrowski majority who might have insisted on resurrection of Douglas and silent burial of the forgotten precedents as the price of their votes. Justice White is a possibility, 227 but his vote was not essential. Since only seven Justices participated in the decision, Justice Brennan could have written for a majority of four. Justice White's vote would be desired, but not at the cost of knowingly resurrecting Douglas and distorting the precedents. Even if Justice Brennan feared that the two Justices not participating in Dombrowski would later join Justice White and the two dissenters to make a majority for overruling the case, he would have been on stronger ground defending Dombrowski as a four-Justice opinion solidly based on decades of precedent than as, a five-Justice opinion purporting to carve an innovative exception to Douglas.

The essential votes, therefore, were those of Justices Brennan, Warren, Douglas and Goldberg. None of these Justices can reasonably be thought to have knowingly demanded a return to Douglas. All of them joined the five-man majority in Cameron $I,{ }^{228}$ which the Court summarily remanded for reconsideration despite vigorous dissents arguing that prospective relief should be denied and that the remand implied a dangerously broad construction of Dombrowski.

Parker v. Brown, 75 Colum. L. Rev. 328, 331-34 (1975); Wechsler, supra note 30, at 799-813, 827-33.

224 Most notably, Burford v. Sun Oil Co., 319 U.S. 315 (1943); Douglas v. City of Jeannette, 319 U.S. 157 (1943); Parker v. Brown, 317 U.S. 341 (1943); Railroad Comm'n v. Pullman Co., 312 U.S. 496 (1941).

${ }_{225}$ See, e.g., Ferguson v. Skrupa, 372 U.S. 726, 728-32 (1963); Day-Brite Lighting, Inc. v. Missouri, 342 U.S. 421, 423-24 (1952); E. Corwin, Court Over Constitution (1938); G. Gunther, Cases and Materials on Constitutional Law 564-65 (9th ed. 1975).

2za See B. MarshaLl, supra note 132.

223 See Trainor v. Hernandez, 431 U.S. 434 (1977) (opinion for the Court); Wooley v. Maynard, 430 U.S. 705, 717-19 (1977) (dissenting); Hicks v. Miranda, 422 U.S. 332 (1975) (opinion for the Court); Allee v. Medrano, 416 U.S. 802, 821-60 (1974) (joining Burger, C.J., dissenting); O'Shea v. Littleton, 414 U.S. 488 (1974) (opinion for the Court); Cameron v. Johnson, 381 U.S. 741, 754-59 (1965) (dissenting).

22x 381 U.S. 741 (1965). 
Justice White wrote one of these dissents. If anyone had joined Justice White in a bargaining bloc that forced the resurrection of Douglas, it is unlikely that he would have abandoned the bloc six weeks later when it had the chance to keep Dombrowski's exceptions narrowly confined. ${ }^{228}$

There is further evidence concerning Justices Brennan, Warren, and Douglas in their dissenting votes a year later in City of Greenwood v. Peacock:230 In Peacock, they would have allowed state prosecutions to be removed to federal court on allegations that the prosecutions were racially motivated and that the state court would not provide fair trials. Sanctioning removal of a pending prosecution is a greater interference with state proceedings than enjoining a threatened one, ${ }^{231}$ and finding as a fact that a judge or jury will be unfair is a greater affront to state courts than invalidating a state law. ${ }^{232}$ Like Dombrowski, the Peacock dissent was squarely inconsistent with precedent, ${ }^{233}$ but unlike Dombrowski, the reversal of precedent would have expanded federal power. It is possible that the same justices deliberately moved so aggressively in such opposite directions on issues they recognized as "close kin," bility seems implausible even allowing for the turbulence of the intervening year. Although Justice Goldberg did not participate in Peacock-he had resigned from the Court-there is other evidence for him: his postresignation references to Dombrowski portray it as a desirable expansion of federal remedies. ${ }^{235}$

Justice Brennan's subsequent opinions in Cameron II, ${ }^{236}$ Younger $v$. Harris, ${ }^{237}$ and Samuels $v$. Mackell, ${ }^{238}$ the first of which was joined by Chief Justice Warren just before he-retired, give rise to a barely colorable argument that Justice Brennan and Chief Justice Warren were hostile to propective relief and hence could have known what they were doing in Dombrowski. But the contrary evi-

233 On the importance of the remand in Cameron I, see Bailey, supra note 27, at 107-09.

220384 U.S. 808 (1966).

201 See Steffel v. Thompson, 415 U.S. 452, 462 (1974); City of Greenwood v. Peacock, 384 U.S. 808, 846 (1966) (Douglas, J., dissenting); Laycock, supra note 5, at 226, 228-29, 235-37.

232 Fiss, supra note 17, at 1116-17.

233 As to Peacock, see 384 U.S. at 848-52 (Douglas, J., dissenting).

${ }^{234} 384$ U.S. at 846 (Douglas, J., dissenting, joined by Warren, C.J., Brennan \& Fortas, J.J.).

255 A. Goldberg, Equal Justice: The Warren Era of the Supreme Court 24-25 (1971); Goldberg, Mr. Justice Brennan and the First Amendment, 4 Rut.-CaM. L.J. 8, 43 n.216 (1972).

236390 U.S. 611 (1968).

277401 U.S. 37, 56-58 (1971) (concurring).

23401 U.S. 66, 75-76 (1971) (concurring). 
dence is overwhelming. In addition to their votes in Peacock and Cameron I, there are all of Justice Brennan's votes and opinions supporting prospective relief in cases in which, like Dombrowski, no enforcement proceeding was pending. ${ }^{239}$ Especially in light of Professor Fiss's analysis of Justice Brennan's strategy, ${ }^{240}$ the Cameron II, Younger, and Samuels opinions are more plausibly viewed as products of a single mistake originating in Dombrowski than as evidence that Dombrowski was deliberate.

Finally, the policy theory cannot account for Dombrowski's widespread reception as a victory for the civil rights movement. Justice Douglas certainly was not hostile to federal prospective relief, ${ }^{241}$ and he refused to accept compromises on the issue. He dissented in Cameron II and wrote separately in most of the important Younger cases before his retirement. His failure to write separately in Dombrowski is strong evidence that he was not aware of any scheme for deliberate retrenchment. The reaction of the practicing and academic bar is more probative yet. Even if there were a conspiracy on the Court to conceal the forgotten precedents, there would have been no such conspiracy among the civil rights bar, and the Court could not have abandoned those precedents without protest. The policy theory must therefore be rejected.

The oversight theory is only slightly less implausible. It is difficult to believe that the Dombrowski majority simply forgot the procedural route by which so many constitutional cases had come to the Court. Prospective relief had been ordered four times the pre-

23y Doran v. Salem Inn, Inc., 422 U.S. 922 (1975) (joining majority); Hicks v. Miranda, 422 U.S. 332, 353-57 (1975) (joining Stewart, J., dissenting); Steffel v. Thompson, 415 U.S. 452 (1974) (opinion of the Court); Lake Carriers' Ass'n v. MacMullan, 406 U.S. 498 (1972) (opinion of the Court); Perez v. Ledesma, 401 U.S. 82, 93-136 (1971) (dissenting in part); cf. Trainor v. Hernandez, 431 U.S. 434, 450-60 (1977) (dissenting) (civil enforcement proceeding pending); Wooley v. Maynard, 430 U.S. 705 (1977) (joining majority) (prosecution no longer pending because not appealed); Juidice v. Vail, 430 U.S. 327, 341-48 (1977) (dissenting) (civil enforcement proceeding pending); Huffman v. Pursue, Ltd., 420 U.S. 592, $611-18$ (1975) (dissenting) (civil enforcement proceeding no longer pending because not appealed).

${ }^{210}$ See text at notes 206-207 supra.

24I See Doran v. Salem Inn, Inc., 422 U.S. 922, 934 (1975) (dissenting in part); Hicks v. Miranda, 422 U.S. 332, 353-57 (1975) Goining Stewart, J., dissenting); Huffman v. Pursue, Ltd., 420 U.S. 592, 618 (1975) (dissenting); Allee v. Medrano, 416 U.S. 802 (1974) (opinion for the Court); O'Shea v. Littleton, 414 U.S. 488, 505-13 (1974) (dissenting); Dyson v. Stein, 401 U.S. 200, 204-15 (1971) (dissenting); Perez v. Ledesma, 401 U.S. 82, 90-93 (1971) (dissenting in part); Samuels v. Mackell, 401 U.S. 66, $74-75$ (1971) (concurring); Younger v. Harris, 401 U.S. 37, 58-65 (1971) (dissenting); Cameron v. Johnson, 390 U.S. 611, 622-28 (1968) (joining Fortas, J., dissenting); England v. Louisiana State Bd. of Medical Examiners, 375 U.S. 411, 423-37 (1964) (concurring); Pugach v. Dollinger, 365 U.S. 458, 462 n.3 (1961) (dissenting); Switchmen's Union v. National Mediation Bd., 320 U.S. 297, 306 (1943) (opinion for the Court). 
vious term and eleven times in the previous four years. ${ }^{242}$ Some of the opinions granting prospective relief had discussed the irreparable injury issue, ${ }^{243}$ and many of the recent cases had discussed other procedural issues raised by requests for prospective relief, such as Pullman abstention, ${ }^{244}$ standing, ${ }^{245}$ construction of the Three-Judge Court Act, ${ }^{248}$ imminence of prosecution, ${ }^{247}$ and justiciability. ${ }^{248}$ That the majority in Dombrowski-and apparently most of the profession-believed the Douglas dictum to have been the last word on irreparable injury seems incredible.

Yet there were factors at work to make such an oversight possible. The most important was the plaintiffs' failure to brief the forgotten precedents. They acknowledged the authority of Douglas and sought to distinguish it, offering the core of what Justice Brennan developed into the overbreadth exception. ${ }^{249}$ They did not argue, even in the alternative, that Douglas was wrong or had been seriously eroded by subsequent Supreme Court authority. Although two of the Supreme Court's post-Douglas prospective relief cases were briefly described in footnotes, ${ }^{250}$ plaintiffs relied primarily on lower court decisions. It is possible that the plaintiffs made a strategic choice to urge only the narrowest ground for reversal, but it appears that they were unaware of the most important post-Douglas developments.

It would not have been impossible for the plaintiffs' counsel and the Supreme Court law clerks to overlook the forgotten precedents, for they had never been very visible: most of the cases that eroded Douglas did not cite it, it had never been squarely disapproved, its dictum had occasionally been quoted with approval, and Shepard's

212 See notes 98,100 supra.

233 See text at notes 73-91, 104-123 supra.

2us Hostetter v. Idlewild Bon Voyage Liquor Corp., 377 U.S. 324, 328-29 (1964); England v. Louisiana State Bd. of Medical Examiners, 375 U.S. 411 (1964); Turner v. City of Memphis, 369 U.S. 350, 353-54 (1962); Two Guys, Inc. v. McGinley, 366 U.S. 582, 589 (1961); Harrison v. NAACP, 360 U.S. 167 (1959); City of Chicago v. Atchison, T. \& S.F. Ry., 357 U.S. 77, 84 (1958); see D. CuRRIE, supra note 34 , at 746.

${ }_{245}$ Bailey v. Patterson, 369 U.S. 31, 32-33 (1962); City of Chicago v. Atchison, T. \& S.F. Ry., 357 U.S. 77, 83-84 (1958).

${ }^{246}$ Idlewild Bon Voyage Liquor Corp. v. Epstein, 370 U.S. 713 (1962); Turner v. City of Memphis, 369 U.S. 350, 353 (1962); Florida Lime \& Avocado Growers, Inc. v. Jacobsen, 362 U.S. 73, 75-85 (1960); see D. CuRrIE, supra note 34, at 746.

${ }_{217}$ Two Guys, Inc. v. McGinley, 366 U.S. 582, 588-89 (1961).

24k Times Film Corp. v. City of Chicago, 365 U.S. 43, 45.46 (1961); Evers v. Dwyer, 358

U.S. 202, 203-04 (1958).

240 Brief for Appellants and Appellants-Intervenors at 82-89, Dombrowski v. Pfister, 380

U.S. 479 (1965).

$250 \mathrm{Id}$. at $87-88 \mathrm{nn} .52 \& 53$. 
Citations gave little hint of what had happened. ${ }^{251}$ Many of the cases were not digested, and those that were appeared under different key numbers than Douglas. ${ }^{252}$ The leading casebook set forth the Douglas dictum as good law. ${ }^{253}$ Even the Assistant Attorney General for the Civil Rights Division apparently did not know about the forgotten precedents. ${ }^{254}$

Obviously the forgotten precedents could have been found; indeed, the Court appears to have known about at least one of them..$^{255}$ But superficial research was not sufficient to find the others. Patience and indirect research methods were required, and it would have helped to have been confident the cases would turn up if one just kept looking. If everyone started out with the impression that Douglas was the law, Dombrowski could have been briefed and decided without discovery of the error.

The oversight theory also largely accounts for the bar's reaction to Dombrowski. The factors that caused the Court to overlook the forgotten precedents would also have affected the rest of the profession. One must wonder why none of the many lawyers who had filed the suits that resulted in the forgotten precedents did not expose Dombrowski's error, but there are possible explanations even for that. As the briefs in Dombrowski and other cases indicate, some lawyers filed such suits without knowing about enough of the forgotten precedents to recognize the pattern and argue that Douglas was dead. Of those who knew, some may have remained silent because they found Dombrowski acceptable on balance. By granting prospective relief even though a prosecution was arguably pending, Dombrowski seemed to give plaintiffs extra time to get to the courthouse. ${ }^{258}$ One commentator plausibly viewed the remand in Cameron $I$ as promising expansion of Dombrowski's exceptions. ${ }^{257}$ Another thought it sufficient that Dombrowski had secured prospective relief in first amendment cases. ${ }^{258}$ Of the lawyers who did know

${ }^{251}$ See United States v. Wood, 295 F.2d 772, 786 (5th Cir. 1961)(Cameron, J., dissenting) ("Shepard's Citations show that the case has been cited one hundred forty times and, until the majority opinion here, its binding force had been questioned only [once].")

${ }^{2 s 2}$ Compare 13 Modern Federal Practice Digest Courts $\S 262.4(5)$ (1960) with 15 id. $\S$ 508(7) and 27A id. Injunctions $\$ 105(1)$ (1969).

233 H. Hart \& H. Wechsler, The Federal Courts and the Federal System 862 (1st ed. 1953); see Wechsler, supra note 30 , at 822 n.333 (attaching great importance to this mistake).

25: See B. Marshall, supra note 132, at 53-54.

${ }_{25 s}$ See Zemel v. Rusk, 381 U.S. 1, 19 (1965) (citing Evers v. Dwyer, 358 U.S. 202 (1958)); text at notes 111-115 supra.

2ss See text at notes 16-18 supra.

${ }^{257}$ Bailey, supra note 27, at 107-09.

2s* Wechsler, supra note 30 , at 843-45. 
about the forgotten precedents, some must have been full-time practitioners with no interest in publishing. Finally, once Dombrowski was written and the initial wave of commentary failed to expose the oversight, the forgotten precedents were buried more deeply than ever.

A variation on the oversight theory is that the Court was aware of the forgotten precedents but thought them distinguishable from Douglas and Dombrowski. Perhaps in the mental maps of the Vinson and Warren Courts there was a Douglas-Dombrowski line of cases and a Toomer-Young line of cases, with a distinction between them so obvious to lawyers of the time that it was never stated, with the result that it has now been lost. Such a supposition might explain Justice Douglas's remarkable concurrence in England $v$. Louisiana State Board of Medical Examiners, ${ }^{259}$ in which, in a single opinion, he denounced the Pullman abstention doctrine as a serious interference with the right to bring constitutional challenges to state statutes in federal court and repeated the Douglas dictum. ${ }^{260}$

But there are fatal problems with the lost-distinction theory. There is a total lack of evidence that such a distinction ever existed and considerable evidence that it did not. Dombrowski itself tends to negate this theory, for it did not distinguish Douglas from Young but rather treated Douglas as having modified Young. There is no mention of such a distinction in any of the numerous postDombrowski analyses of prospective relief. There is also no way to explain how a distinction so obvious and well understood as never to require any mention could be so thoroughly forgotten so quickly. Nor is there any way to explain why not one case from the DouglasDombrowski line reached the Supreme Court in the sixteen years between Stainback and Dombrowski. Such cases were common in the Supreme Court in the early forties and again after Dombrowski, and were common in the lower courts throughout the period when only Toomer-Young cases reached the Supreme Court; ${ }^{261}$ moreover, they were often within the Court's mandatory jurisdiction. ${ }^{262}$

More importantly, there are places where such a distinction would have to be mentioned if it existed. In particular, it would inevitably have been noted in the opinions of lower courts puzzled by Douglas and in the Supreme Court briefs arguing over the applicability of Douglas. These sources reflect attempts to make sense of

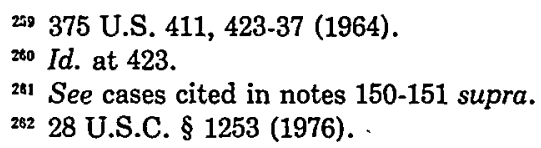


the conflicting cases and properly categorize a particular case in some existing framework; if there were some well-known distinction that explained everything, it would be mentioned here. It is not. Indeed, defendants and some lower courts concluded that there was no distinction, that Douglas controlled. ${ }^{263}$ Some plaintiffs simply cited cases such as Toomer and made no effort to explain Douglas. ${ }^{264}$ Some judges and litigants offered subtle distinctions to explain the cases, but their suggestions are so wildly inconsistent as to belie the existence of any well-known, settled distinction. ${ }^{265}$

There are only three arguments that may represent attempts to divide all the cases into two clean categories; none comes close to fitting the cases. The suggestion that prospective relief issued only in civil rights or civil liberties cases ${ }^{266}$ is the most clearly erroneous, for the leading cases in each supposed line are all in the wrong categories: Douglas and Dombrowski were civil liberties cases and

${ }^{243}$ See United States v. Wood, 295 F.2d 772, 786-87 (5th Cir. 1961) (Cameron, J., dissenting); Motion to Affirm at 7, Brief for Appellees at 17-20, Doud v. Hodge, 350 U.S. 485 (1956); Brief for Appellee, J. Tom Watson at 13-17, AFL v. Watson, 327 U.S. 582 (1946).

24 Appellants' Jurisdictional Statement at 4-5, Appellants' Brief at 52, Florida Lime \& Avocado Growers, Inc. v. Jacobsen, 362 U.S. 73 (1960); Brief for Appellees at 22-23, Morey v. Doud, 354 U.S. 457 (1957).

205 Brief for Appellants at 7-12, Paul v. Florida Lime \& Avocado Growers, Inc., 373 U.S. 132 (1963) (distinction depends on extent of harm shown by plaintiff); Jurisdictional Statement at 27, Bailey v. Patterson, 369 U.S. 31 (1962) (state remedy adequate in Douglas but inadequate in Bailey); Appellee's Motion to Affirm at 7, Gremillion v. United States, 368 U.S. 11 (1961) (state prosecution in Gremillion brought with purpose and effect of frustrating earlier federal court order); Brief for Appellants at 40, Gallagher v. Crown Kosher Super Mkt., Inc., 366 U.S. 617 (1961) (exception to Douglas for cases involving exceptional circumstances, substantial constitutional claim, and great and immediate danger of irreparable loss of property rights); Appellee's Brief at $25, i d$. (cases denying prospective relief "usually contain elements of anticipating state construction, or of interference in criminal prosecutions already in progress, or of little or no damage to the parties in awaiting state action", prospective relief will issue "where substantial property damage is inflicted by enforcement . . . where multiple prosecutions . . . are threatened [or] where basic civil or constitutional rights are involved"); Motion to Dismiss or Affirm at 12-13, Florida Lime \& Avocado Growers, Inc. v. Jacobsen, 362 U.S. 73 (1960) (cases in which plaintiffs could not conduct business without violating statute distinguished from cases in which plaintiffs could operate in compliance; race cases distinguished on ground that racial identity is unchangeable); Appellee's Brief at 29-34, id. (distinction depends on extent of harm to plaintiffs); Jurisdictional Statement at 15, Brief for Appellants at 27-28, Morey v. Doud, 354 U.S. 457 (1957) (exceptions to Douglas for statutes with severe penalties and plaintiffs whose "successful business . . . suddenly finds its very existence threatened by exceptional circumstances of a very serious nature"); Brief Opposing Motion to Affirm at 8-9, Doud v. Hodge, 350 U.S. 485 (1956) (Doud dismissed below for lack of jurisdiction but Douglas upheld jurisdiction; statutes with and without severable sections distinguished); Appellant's Brief at 31-37, AFL v. Watson, 327 U.S. 582 (1946) (injury in AFL great and immediate, but not in Douglas).

211 See cases cited in notes 145 \& 149 supra; Jurisdictional Statement at 27-28, Bailey v. Patterson, 369 U.S. 31 (1962); Motion to Affirm at 7-8, Gremillion v. United States, 368 U.S. 11 (1961); Maraist, supra note 30, at 548-52. 
Young and Toomer were economic regulation cases. ${ }^{267}$ The opposite theory-that prospective relief issued only to protect property rights-has also been suggested, ${ }^{268}$ but scores of civil rights cases are available to refute it. ${ }^{288}$

The remaining suggestion is that the Court would enjoin enforcement of a state policy although it would not enjoin a criminal prosecution. ${ }^{270}$ But the distinction would make no sense whenever it was applied to policies backed by criminal penalties, for an injunction against enforcement of the policy would be an injunction against prosecutions to enforce it. One way to make sense of this suggestion, although not the way its proponents intended, is to view the Court as having authorized prospective relief only when no particular prosecution was threatened. But this understanding states the Court's approach exactly backwards; prospective relief would not issue unless there were a threat. ${ }^{271}$ The defendants in Steffel $v$. Thompson ${ }^{272}$ tried to avoid that difficulty by urging three categories upon the Court: cases with an "imminent threat of state prosecution," cases without a threat of prosecution but with a "direct threat of personal detriment," and cases with "only a speculative future application of the state law." 273 They would have allowed prospective relief only in the second category, but the Court rejected the proffered distinction. Moreover, the imminence or explicitness of the threat of prosecution explains the cases no better than the civil rights distinction. ${ }^{274} \mathrm{~A}$ review of all the cases suggests no other possible distinction; they simply cannot be categorized in a way that accounts for the different approaches to prospective relief. The lostdistinction theory must also be rejected.

Any explanation of Dombrowski's break with precedent is of course speculative. The most likely explanation, however, as sur-

${ }^{267}$ See also text and notes at notes 97-101 supra.

${ }^{268}$ Jurisdictional Statement on Behalf of Appellants at 9, Gremillion v. United States,

368 U.S. 11 (1961); Brief for Appellants at 11-12, Doud v. Hodge, 350 U.S. 485 (1956).

${ }^{268}$ See, for example, cases cited in notes 98 \& 99 supra.

270 Motion to Affirm at 3-4, Gayle v. Browder, 352 U.S. 903 (1956).

27 E.g., Dombrowski v. Pfister, 380 U.S. at 484 n.2, 496 n.13; see text and note at note 15 supra.

272415 U.S. 452 (1974).

${ }^{273}$ Brief for Respondents Hudgens and Reynolds at 7-8, Steffel v. Thompson, 415 U.S. 452 (1974).

${ }^{274}$ Compare AFL v. Watson, 327 U.S. 582 (1946) (vigorous state enforcement effort with explicit threats and some proceedings already pending; prospective relief authorized) with Douglas v. City of Jeannette, 319 U.S. 157 (1943) (same; prospective relief denied). Compare Ex parte Young, 209 U.S. 123 (1908) (enforcement proceeding filed immediately after federal suit; prospective relief granted) with Dombrowski v. Pfister, 380 U.S. 479 (1965) (same; prospective relief authorized but only as part of a narrow exception to Douglas). 
prising as it seems, is that a simultaneous breakdown of the briefing system, the legal research tools, and the Justices' own memories caused the Court to adopt by mistake a rule that was supported neither by precedent nor by the policy preferences of the majority.

\section{The Duty of Correction}

Anglo-American law relies heavily on judicial decisions to formulate and transmit legal rules. ${ }^{275}$ This system has been repeatedly criticized for obscuring the law in a great mass of relatively unorganized printed matter and making it impossible to learn the law on any particular point without extensive research. ${ }^{276}$ Dombrowski lends new force to such criticisms. The disappearance without comment of a large body of decisions and the reversal of a legal rule without public recognition of the change could only have resulted from a systemic malfunction. It is unlikely that major oversights occur with enough frequency to raise serious concern about the reliability of judicial opinions as a repository for legal doctrine, ${ }^{277}$ but that possibility poses an intriguing empirical question. It in turn raises the broader issue of the relative frequency of inadvertant doctrinal discontinuities in common-law and civil-law systems, an issue that should be of interest to scholars investigating the comparative advantages of emphasizing precedent or code in the operation of law.

Dombrowski also raises the quite practical question of how a court should respond when it discovers that one of its precedents is based on an oversight. Significantly, in other, less dramatic instances in which the Supreme Court has discovered that an oversight contributed to an erroneous precedent, it has corrected its mistake.

In Trustees of the Philadelphia Baptist Association v. Hart's Executors, ${ }^{278}$ the Court held that there could be no charitable trust without statutory authorization, because charitable trusts in England had depended on a statute enacted in $1601 .{ }^{279}$ In Vidal v. Gir-

27s See Landes \& Posner, supra note 219, at 249-50, 271-75.

z76 J. Kent, Commentaries on American Law *473-75; R. Pollard, SpeEd-up Law Reform 6-7 (1958); Lloyd, Codifying English Law, 2 Current Legal Prob. 155 (1949); Stone, A Primer on Codification, 29 Tuz. L. REv. 303, 304 (1955); Van Hecke, A Civilian Looks at the Common-Law Lawyer in Parker School Studies in Foreign and Comparative Law, 30th ANniversary Symposium: Internatonal Contracts 5, 6-7 (W. Reese ed. 1962).

$2 \pi$ See K. Llewellyn, The Common Law Tradition (1960). But see J. Kent, supra note 276, at * 473-75; K. LLEWELLyN, supra, at 85, 133-35, 256-60, 305, 450-60; Lobingier, Precedent in Past and Present Legal Systems, 44 Mich. L. REv. 955, 984-86 (1946).

77x 17 U.S. (4 Wheat.) 1 (1819).

"7" 43 Eliz., c.4 (1601). 
ard's Executors, ${ }^{280}$ the Court reached the opposite result, citing "very strong additional light . . . thrown upon this subject" by the subsequent publication of historical records showing that charitable trusts were enforced before 1601 and hence without the aid of statute. ${ }^{281}$ In United States $v$. Murdock, ${ }^{282}$ the Court cited King of the Two Sicilies $v$. Willcox ${ }^{283}$ for what it thought was the English rule that the privilege against self-incrimination did not protect against incrimination under the laws of another sovereign. The Court was unaware that Sicilies had been disapproved shortly after it was decided, ${ }^{284}$ and discovery of this error played an important role in the Warren Court's opinion overruling Murdock. ${ }^{285}$ Similarly, the decision in Swift $v$. Tyson ${ }^{286}$ that state common law does not control in federal diversity cases was surely affected by the Court's ignorance of the original draft of the Rules of Decision Act. ${ }^{287}$ Professor Warren's subsequent discovery of the draft ${ }^{288}$ contributed to the overruling of Swift in Erie Railroad v. Tompkins. ${ }^{289}$

Most recently, in Monroe v. Pape, ${ }^{290}$ the Court concluded that the Civil Rights Act of $1871^{291}$ created no cause of action against municipalities. This conclusion was based on a fallacious inference from one bit of legislative history-rejection of the Sherman Amendment-and apparent unawareness of a much larger body of legislative history pointing to an opposite conclusion. ${ }^{292}$ Monroe resembles Dombrowski in that the issue had not been briefed..$^{293}$ There was even a line of inconsistent cases, somewhat analagous to the forgotten precedents, mainly involving suits against school boards. ${ }^{294}$ Apparently the Court thought school boards distinguishable from municipalities. But the distinction collapsed on analysis because both school boards and municipalities were separately in-

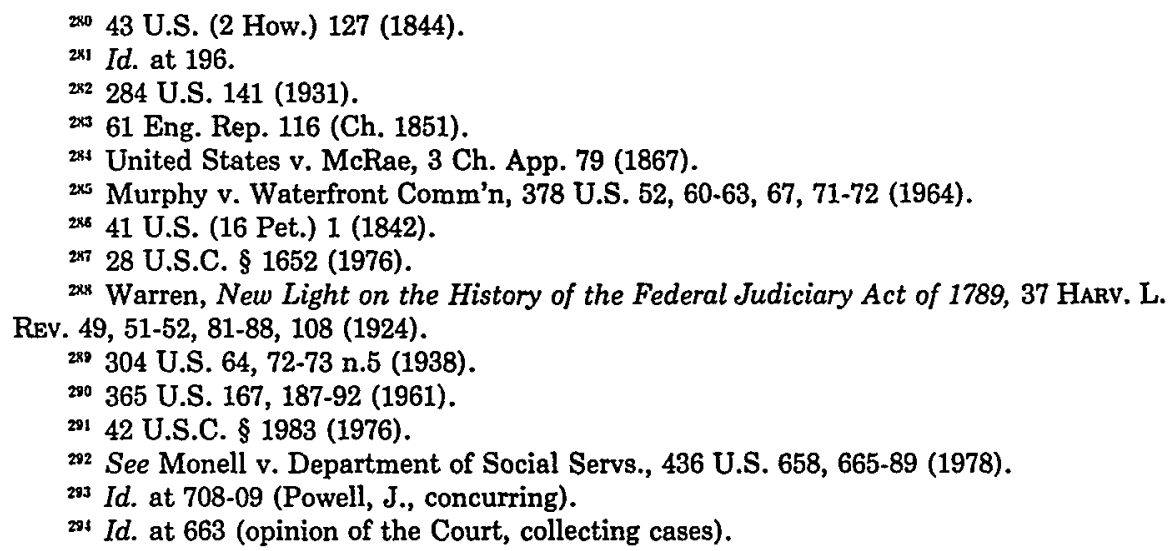


corporated units of local government. ${ }^{295}$ Recognition of the relevance of this second line of cases and discovery of the additional legislative history contributed to the overruling of Monroe in Monell $v$. Department of Social Services. ${ }^{288}$ These overrulings are in accord with the prevailing view in the American literature. ${ }^{297}$ Even in England there is a willingness to correct precedents based on significant oversights. ${ }^{298}$

But Justice Rehnquist's dissenting opinion in Monell challenges this consensus. ${ }^{299} \mathrm{His}$ position appears to be that citizens must be able to rely on any precedent, even one with "obvious flaws" or one based on grounds that were " "never actually briefed and argued." "300 $\mathrm{He}$ sees this as a "necessary by-product of the adversary system," which relies "upon litigants to present 'all the relevant considerations," "301 and concludes that any other rule "would introduce intolerable uncertainty into the law." ${ }^{02}$ Justice Rehnquist does not argue that precedent can never be overruled, but he does say that overrulings require an extraordinary showing and that it is irrelevant whether the erroneous earlier decision was the result of an oversight.

Justice Rehnquist's position is seriously flawed. The Court's well-developed criteria for prospective overruling are sufficient to accommodate any genuine reliance interests. ${ }^{303}$ In his apparent

${ }^{235}$ Id. at 695-99; id. at 710-12 (Powell, J., concurring).

236 Id. at 663 (opinion of the Court).

20 See A. GoldBERG, supra note 235, at 79-81; J. KENT, supra note 276, at *475-78; K. LLEWELLYN, supra note 277, at 291-94; Lobingier, supra note 277, at 973-74; Noland, Stare Decisis and the Overruling of Constitutional Decisions in the Warren Years, 4 VAL. L. REv. 101, 110 (1969). See also Rivota v. Fidelity \& Guar. Life Ins. Co., 497 F.2d 1225, 1229 (7th Cir. 1974).

218 See Morrelle Ltd. v. Wakeling, [1955] 2 Q.B. 379, 398-407 (C.A.); Young v. Bristol Aeroplane Co., [1944] K.B. 718, 728-30 (C.A.); R. Cross, Precedent in English Law 13436, 143-44 (3d ed. 1977). See also Practice Statement of the House of Lords, reprinted in id. at 109; London St. Tramways Co. v. London County Council, [1898] A.C. 375 (H.L.).

219 436 U.S. at 717-18. But see Chapman v. Houston Welfare Rights Org., 99 S. Ct. 1905, 1929-30 (1979) (Powell, J., concurring, joined by Rehnquist, J.) (relying on Monell's treatment of oversight); City of Columbus v. Leonard, 99 S.Ct. 3097, 3101 (1979) (Rehnquist, J., dissenting from denial of certiorari to review 551 F.2d 974 (5th Cir. 1977)) ("The Court having reopened [part] . . . of Monroe v. Pape, I would . . . reconsider" Monroe's rule that exhaustion of state remedies is not required under 42 U.S.C. $\$ 1983$ (1970). That rule "was reached in an almost off-the-cuff manner.").

${ }^{300} 436$ U.S. at 718 (internal quotation from 436 U.S. at 708 (Powell, J. concurring)).

${ }^{201}$ Id. (internal quotation from 436 U.S. at 709 n.6 (Powell, J., concurring)); see Landes \& Posner, supra note 219, at 272.

302436 U.S. at 718.

${ }^{303}$ See Chevron Oil Co. v. Huson, 404 U.S. 97, 105.09 (1971); Linkletter v. Walker, 381 U.S. 618 (1965); England v. Louisiana State Bd. of Medical Examiners, 375 U.S. 411, 422 (1964); Great N. Ry. v. Sunburst Oil \& Ref. Co., 287 U.S. 358, 363-66 (1932); Gelpcke v. 
quest for certainty for its own sake, Justice Rehnquist goes far beyond insisting that the Court refrain from second guessing its earlier judgments on matters of policy or interpretation. He would commit the Court to perpetuating its least defensible blunders-cases in which the Court erred because it failed even to consider the most telling authority or argument for the losing side, or in which its conclusion was not subjected to the discipline of writing an opinion $^{304}$ that would be open to criticism by the profession. ${ }^{305}$

The necessities of the adversary system may require that when an attorney fails to call the Court's attention to a key point, the litigant who hired him must suffer the resulting injustice. This principle is part of the law of res judicata. ${ }^{308}$ But nothing requires that an innocent population live indefinitely under an erroneous rule of law just because the first lawyer to take the issue before the Court made an inadequate argument. Nothing was decided concerning arguments he did not make. To make precedents binding with respect to all arguments that could have been made is to convert stare decisis into a form of res judicata without the safeguard of limitation to parties and their privies. Even statutes are not so binding, for any citizen may petition for amendment or repeal at any time.

Justice Rehnquist's proposed rule would also have other undesirable consequences. It would aggravate the existing pressure on attorneys with novel arguments to get a case to the Court before someone else makes bad law. ${ }^{307}$ Second, because a Court unable to

City of Dubuque, 68-U.S. (1 Wall.) 175 (1863); K. LlEwELLYN, supra note 277, at 299-305; Leflar, Sources of Judge-Made Law, 24 OKLA. L. Rev. 319, 333-35 (1971). See also Harlin v. Missouri, 99 S. Ct. 709, 710 (1979) (Powell, J., concurring).

sos See Edelman v. Jordan, 415 U.S. 651, 670-71 (1974) (Rehnquist, J., for the Court); K. Llewellyn, supra note 277, at 26-28, 287-91; Leflar, supra note 303, at 319; Smith, $A$ Primer of Opinion Writing, For Four New Judges, 21 ARK. L. REv. 197, 201 (1967).

${ }^{305}$ On the importance to judicial law-making of scholarly criticism, see K. LLEWELLYN, supra note 277, at 29-31, 345-55, 460-61 (1960); Kurland, Preface, 1960 Sup. CT. Rev. vii; id. at ii (quoting Chief Justice Harlan Stone and Judge Learned Hand); Leflar, supra note 303, at 319, 323, 336; Rheinstein, Common Law and Civil Law, 22 Revista JuridicA DE LA UNIversIDAD DE PUERTo Rico 90, 102 (1952); Smith, supra note 304 at 200-01; Swygert, Introduction, 50 Chi.-Kent L. Rev. 181, 181 (1973). See also City of Columbus v. Leonard, 99 S.Ct. 3097 , 3101 (1979) (Rehnquist, J., dissenting from denial of certiorari to review 551 F.2d 974 (5th Cir. 1977)) (relying on scholarly criticism of case he wished to overrule); Bridges v. California, 314 U.S. 252, 284, 289-90 (1941) (Frankfurter, J., dissenting).

${ }^{308}$ Sea-Land Servs., Inc. v. Gaudet, 414 U.S. 573, 578-79 (1974) (quoting Commissioner v. Sunnen, 333 U.S. 591, 597 (1948) and Cromwell v. County of Sac, 94 U.S. (4 Otto) 351, 352 (1877)); United States v. Temple, 299 F.2d 30 (7th Cir. 1962); Matthews v. Wolvin, 266 F.2d 722, 726 (5th Cir. 1959); Orwell v. Hopkins, 28 Cal. 2d 147, 152, 168 P.2d 972 (1946); Panos v. Great W. Packing Co., 21 Cal. 2d 636, 134 P.2d 242 (1943); Cleary, Res Judicata Reexamined, 57 YaLE L.J. 339 (1948).

${ }^{307}$ See, e.g., Petition for a Writ of Certiorari to the United States Court of Appeals for the Third Circuit Before Judgment at 6-9, Caulfield v. Hirsch, 436 U.S. 957 (1978) (urging 
overrule an obviously flawed precedent is likely to subvert or evade it with covert practices, ${ }^{308}$ Justice Rehnquist would encourage the sort of obscurantism that produces oversights in the first place. Finally, Justice Rehnquist would render scholarly criticism of the Court's work largely irrelevant, for no matter what flaws were uncovered, correction would be sharply curtailed.

Justice Rehnquist has not himself been oblivious to the evils of judicial oversight. His opinion for the Court in Edelman v. Jordan ${ }^{309}$ held that summary affirmances ${ }^{310}$ and holdings not explicitly discussed in the opinion, even on issues that were briefed, are entitled to little precedential weight. ${ }^{311}$ In addition, his concurring opinion in Dothard v. Rawlinson ${ }^{312}$ suggests that an argument not made by counsel can remain available to future litigants if some member of the Court thinks of it at the time and mentions it in his opinion.

These opinions cannot be reconciled with his later view in Monell. An opinion's silence on a key argument or line of authority is indistinguishable from silence on an entire issue. The opinion in Monroe demonstrated that most of the legislative history had not been considered just as the sub silentio character of the opinions overruled in Edelman indicated that the Eleventh Amendment issue in those cases had not been fully considered. Indeed, Justice Rehnquist's Dothard opinion reserved an alternative argument not raised by the Court or the parties, which he suggested could be the basis of a later contrary holding on the very issue discussed at length and squarely decided by the majority. The easiest way to reconcile Justice Rehnquist's opinions on judicial oversight is to note that in Edelman and Dothard, but not in Monell, he agreed with the pretermitted argument. Whatever the explanation, his Edelman-Dothard view clearly provides the better rule. The Court's ultimate obliga-

Court to "take into account the additional factual and legal positions advanced by Petitioners," id. at 6 , before deciding a similar case in which certiorari had been granted); C. REMBAR, ThE END of OBsCENITY 45-58, 406-15 (1968) (describing his efforts to get his definition of obscenity before the Court before any other obscenity cases were decided).

sas See K. LLEWELLYN, supra note 277, at 25-26 n.17, 256-58; Stone, The Miranda Doctrine in the Burger Court, 1977 SuP. CT. Rev. 99, 100-01, 168-69.

${ }^{309} 415$ U.S. $651,670-71$ (1974).

s10 For a summary of the present status of summary affirmances, see Washington v. Confederated Bands and Tribes of the Yakima Indian Nation, 99 S. Ct. 740, 749 n.20 (1979). Court).

${ }^{311}$ See also Parker v. Randolph, 99 S. Ct. 2132, 2140 n.8 (1979) (Rehnquist, J., for the

312433 U.S. 321, 337, 339-40 (1977). See also Chapman v. Houston Welfare Rights Org., 99 S. Ct. 1905, 1929-30 (1979) (Powell, J., concurring, joined by Rehnquist, J.) (relying on Monnell's treatment of oversight); City of Columbus v. Leonard, 99 S. Ct. 3097, 3101 (1979) (Rehnquist, J., dissenting from denial of certiorari to review 551 F.2d 974 (5th Cir. 1977)) (same). 
tion "to say what the law is"313 requires it to consider every relevant argument squarely and on the merits, at least once.

The rule that judicial oversights should be corrected when they are discovered was easy to apply to the four examples noted earlier. ${ }^{314}$ The mistaken rule was expressly disapproved and a new rule substituted in a single opinion. Dombrowski is harder to correct, for its most important effects have survived repudiation of its specific rules. Its overbreadth exception was disapproved in Younger $v$. Harris, ${ }^{315}$ and its general rule that constitutional rights should be tested in criminal prosecutions was rejected in Steffel $v$. Thompson..$^{316}$ What remains of Dombrowski is a mistaken sense that Younger is firmly based in precedent and Steffel is an innovation, and a set of consequences that are nonetheless real despite the difficulty of tracing them through the twistings of subsequent doctrinal development. The slight uncertainty concerning the efficacy of declaratory judgments and the availability of injunctions, the prohibition of prospective relief for defendants in pending enforcement proceedings even if they still face the Young dilemma with respect to contemplated future violations, the reverse removal power, and perhaps some collateral consequences of the overblown rhetoric of Younger $v$. Harris-these are the true legacies of Dombrowski.

Still, the Court can repair the most significant damage by announcing that henceforth any plaintiff facing the Young dilemma shall be entitled to prospective relief. In doing so it would be faithful to seventy years of its own precedents and to equally longstainding congressional policy reflected in the uninterrupted existence of the Civil Rights Act of 1871, the Three-Judge Court Act, and the Declaratory Judgment Act. From this perspective the five Douglas dictum cases, the brief period from Dombrowski to Steffel, and the remaining gaps between the Younger doctrine and full recognition of the Young dilemma appear as minor deviations from the scores of cases relieving plaintiffs from the Young dilemma. And even those deviations have been products of oversight or disingenuousness. In the whole history of litigation over prospective relief, only Chief Justice Stone has ever frankly acknowledged the existence of the Young dilemma and argued that other considerations outweighed the need to relieve from it. ${ }^{317}$ Whenever the Court has

${ }^{313}$ United States v. Nixon, 418 U.S. 683, 703 (1974); Marbury v. Madison, 5 U.S. (1 Cranch) 137, 177 (1803).

314 See text and notes at notes 278-296 supra.

3เ 401 U.S. $37,50-52$ (1971).

3is 415 U.S. 452, 460-63 (1974).

31 AFL v. Watson, 327 U.S. 582, 600 (1946) (Stone, C.J., dissenting) ("prosecutions . . . 
denied prospective relief, it has ignored the dilemma and assumed that state remedies were adequate.

I have discussed elsewhere the implications of alternative means of providing adequate remedies for all plaintiffs facing the Young dilemma. ${ }^{318}$ The minimum workable corrective action is clear. First, the Court must end the slight remaining doubt concerning the efficacy of declaratory judgments of unconstitutionality, by adopting Justice White's concurrence in Steffel. ${ }^{319}$ Justice White argues forcefully that citizens can rely on declaratory judgments and that state officials are bound by them. There is no reason why these arguments should not prevail. ${ }^{320}$

Second, the Court should overrule part of Roe $v$. Wade. ${ }^{321}$ This step would be more important and undoubtedly more controversial. Roe is the only case in which a plaintiff squarely asked the Court to enjoin prosecutions for future violations without interfering with his pending prosecutions. The Court refused, without any effort to analyze the issue, and apparently without recognizing that plaintiff faced the Young dilemma in a most acute way: with the prosecutor's attention already focused on him, he had to go to his medical office every day and decide whether to continue performing abortions.

There are signs of movement towards reconsideration of Roe. In Wooley v. Maynard, ${ }^{322}$ the Court affirmed injunctions against further prosecution of a plaintiff who had been convicted three times and had failed to appeal. As I have argued extensively elsewhere, ${ }^{323}$ that result is ultimately inconsistent in principle with Roe, for it distinguishes past from future violations and permits a state defendant to obtain prospective relief from a federal court. This implication was immediately noticed in the lower courts; Wooley was cited as authority for enjoining additional prosecutions of plaintiffs whose

may . . . cause apprehension .... Such apprehensions and those of others may lead to changes in business practice to the injury of the alleged lawbreakers. But . . loss . . . resulting from such proceedings . . . is damnum absque injuria."); Yakus v. United States, 321 U.S. 414, 444 (1944) (Stone, C.J., for the Court) ("Unlike most penal statutes . . . whose validity can be determined only by running the risk of violation . . . the present statute provides . . . an independent administrative proceeding.") (dictum); cf. Younger v. Harris, 401 U.S. 37, 46, 51 (1971) (Black, J., for the Court) (referring, in discussion of overbreadth exception, to "chilling effect that admittedly can result," but insisting in discussion of general rule that criminal prosecution generally provided adequate remedy and referring only to "cost, anxiety, and inconvenience of having to defend").

Jis Laycock, supra note 5, at 218, 228-31, 237-38.

J' 415 U.S. 452, $476-78$ (1974).

${ }^{520}$ See Laycock, supra note 5, at 213.

321410 U.S. 113, 125-27 (1973).

322430 U.S. 705 (1977).

J2 Laycock, supra note 5, at 212-14. 
earlier prosecutions were still pending. ${ }^{324}$

The Supreme Court has not indicated any awareness of the full reach of Wooley's logic. Moreover, the Court recently suggested a bizarre rule that could ultimately be used to limit Wooley's impact, although the significance of the case is limited because it did not involve the Young dilemma and did not cite Wooley. Moore $v$. $S_{S i m s} s^{325}$ involved a federal-court challenge to a Texas statute setting procedures for taking allegedly battered children away from their parents. The Court held that the plaintiffs' constitutional objections to the statute's provisions for collection and dissemination of child abuse information and for ex parte deprivations of custody should be dismissed because, although those objections were not directly relevant to related state court litigation, they could be raised there as permissive counterclaims. ${ }^{326}$ Yet, the Court significantly limited this holding in an ambiguous response to the dissent's suggestion that the pending state proceedings were analogous to a pending traffic ticket-not related in any relevant way to the claims asserted in the federal case. ${ }^{327}$ The Court said the plaintiffs could refrain from filing counterclaims and "simply obtain a resolution of the pending proceeding and then file their separate action," apparently in federal court. 328 This option to return to federal court seems to apply to the plaintiff's actual claims, but it may apply only to hypothetical claims that even the majority would view as completely unrelated to the state litigation.

Waiting until the conclusion of the state litigation to file their federal claim would serve no identifiable federalism interest in Moore. Such a waiting period, however, may be little more than a serious inconvenience to the plaintiffs there. During the waiting period, the plaintiffs will be exposed to the risks that more incorrect or privileged information will be gathered or disseminated and that ex parte procedures will again be invoked against them. But they will not have to refrain from constitutionally protected activity to avoid aggravating those risks. Other applications of Moore might have more harmful consequences. For example, the Court could apply the waiting period rule to distinguish Wooley from Roe, by requiring state defendants to await termination of all litigation over past violations before seeking relief with respect to future violations. The result would be to leave such defendants squarely in the Young

${ }^{324}$ Eagle Books, Inc. v. Ritchie, 455 F. Supp. 73, 75-76 (D. Utah 1977); Sovereign News Co. v. Falke, 448 F. Supp. 306, 376-78 (N.D. Ohio 1977); Boe v. Colello, 438 F. Supp. 145, 151-53 (S.D.N.Y. 1977).

32599 S. Ct. 2371 (1979).

${ }^{326}$ Id. at $2378,2381$.

${ }^{327}$ Id. at 2383-86 (Stevens, J., dissenting).

32x Id. at 2383 n.14. 
dilemma. Such a distinction has also been criticized on other grounds. ${ }^{329}$

Two additional facts color Moore and may limit its implications. The district court had not limited itself to the information and ex parte seizure issues. It had stayed the pending state litigation for a year and a half while it resolved all foreseeable federal issues, including those that clearly should have been raised in the pending state proceedings, such as the procedure and burden of persuasion to be applied there. ${ }^{330}$ Thus, the Supreme Court in Moore was not reviewing a judgment that carefully separated the plaintiffs' claims and gave reasonable deference to state proceedings while preserving the plaintiffs' choice of forum for claims independent of those proceedings. If the Court does review such a judgment in the future, and if the judgment is supported by careful findings of fact, a majority might respond with more attention to differences between claims. The Court's failure to consider the dissent's suggestion that the judgment be modified ${ }^{331}$ is not encouraging, but a dissenting opinion is no substitute for a record that properly shapes the issue.

The second fact that may limit Moore is that the worst harm to the plaintiff-parents had been limited by a federal district court order that the children be returned. The Supreme Court did not review this order, but relied on it to show that further relief had been unnecessary. ${ }^{332}$ This reliance implies at least some willingness to treat separate claims separately, as would be required to overrule Roe and distinguish future from pending prosecutions against the same litigant. Thus, part of Moore undermines Roe even as other parts lend it tangential support against the implications of Wooley. Wooley and Moore neither reaffirm nor overrule Roe, but the questions they raise make the case for its reexamination more compelling.

Finally, there are disputed details of the Younger doctrine that do not involve the Young dilemma. One of these is Hicks $v$. Miranda ${ }^{333}$ the case that created the reverse removal power. If Roe $v$. Wade is overruled, a retaliatory prosecution will not deprive the federal court of power to take a plaintiff out of the Young dilemma by enjoining additional prosecutions for any future violations. Whether the retaliatory prosecution should be allowed to continue

32 Laycock, supra note 5, at 213-14; Fiss, supra note 17, at 1141-42.

330 Sims v. State Dept. of Pub. Welfare, 438 F. Supp. 1179, 1185, 1194-95 (S.D. Tex. 1977), rev'd sub nom. Moore v. Sims, 99 S. Ct. 2371 (1979).

ग3' 99 S. Ct. at 2387 (Stevens, J., dissenting).

22 Id. at 2382-83 (opinion of the Court).

20722 U.S. 332 (1975). 
is a separate issue, independent of the Young dilemma. Correcting the oversight in Dombrowski would not logically compel any particular resolution of that issue, although the interests at stake might be balanced differently in light of a corrected understanding of the history of prospective relief.

\section{ConcLusion}

Dombrowski is a dramatic example of judicial oversight. The Court announced a rule that had not been the law for at least two decades, if ever, that was inconsistent with the overwhelmingly dominant line of precedent for the previous sixty years, and that the majority apparently disagreed with as a matter of policy. Because the mistake went undetected, Dombrowski was greeted as an expan. sion of the right to prospective relief when in fact it was the opposite. An oversight of this magnitude suggests a need for research concerning the causes and frequency of similar incidents. Its continuing doctrinal effects require correction. Prospective relief is subject to more restrictions today than it was before Dombrowski, and the Court has never tested the new restrictions against the full logic of the Young dilemma and the authority of six decades of forgotten precedent. It has an obligation to do so. 